\title{
دراسة زخارف الطراز الأندلسي وتوظيفها في إثراء الملابس النسائية بالتطريز الآلي
}

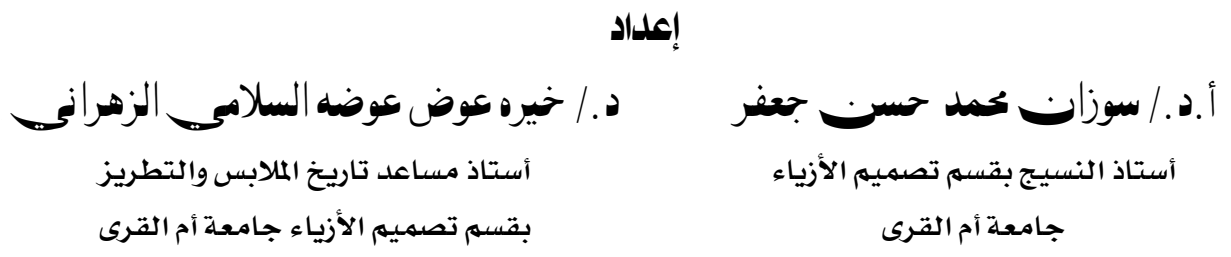

مجلة بحوث التربية النوعية - جامعة المنصورة

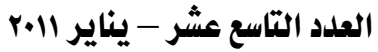




\title{
دراسة زخارف الطراز الأندلسي وتوظيفها في إثراء الملابس النسائية بالتطريز الآلي
}

\author{
إعداد \\ د ـ خيرهعوض عوضهالسلامي الزهراني \\ أ.د . سوزازمحمد حسنجعفز
}

\section{مقدمهة}

تميزت الفنون الإسلامية بأن لها وحدة عامة تجمعها، على أن هذه الوحدة لم تمنع من وجود الإديا

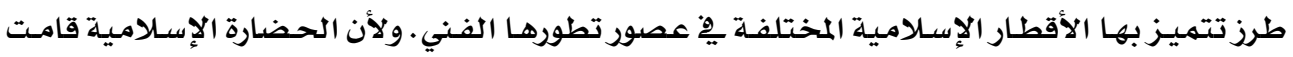

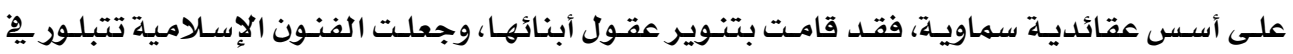

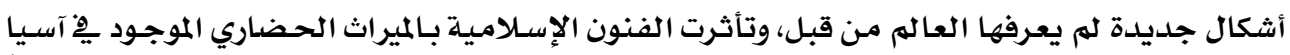

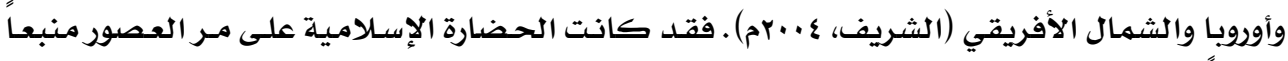

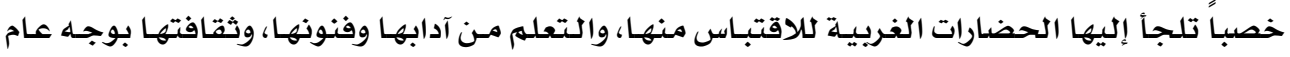

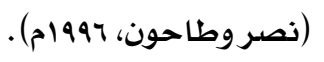

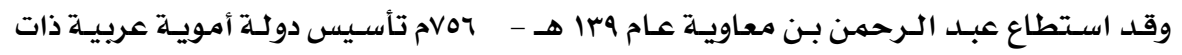

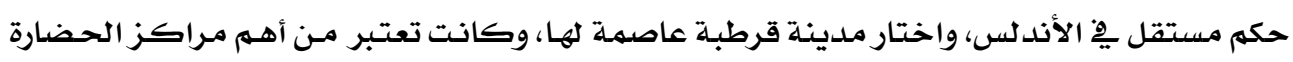

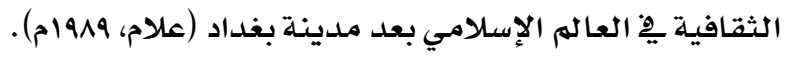

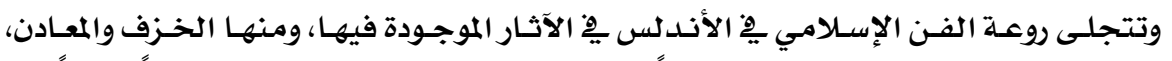

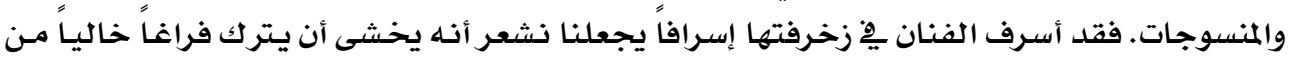

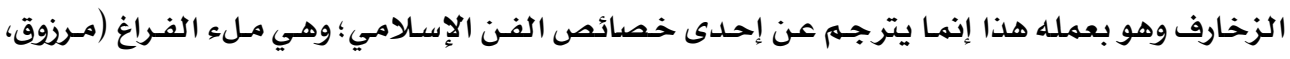

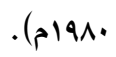

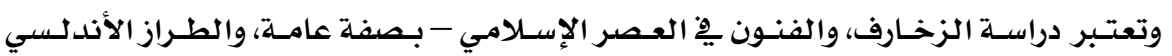

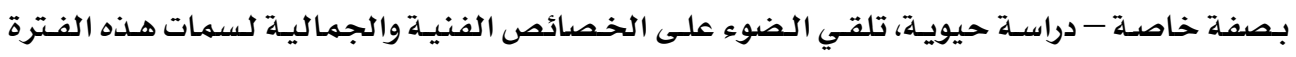

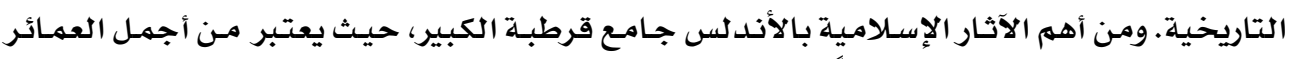

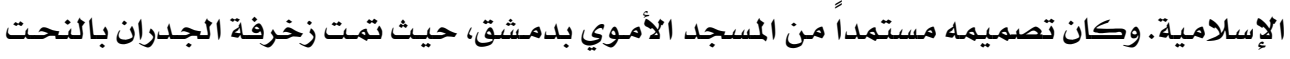

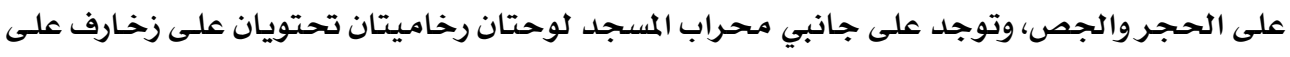

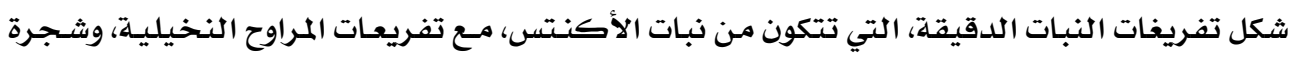

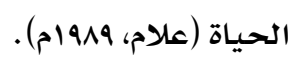

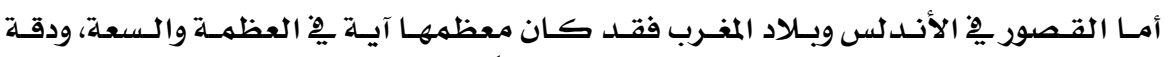

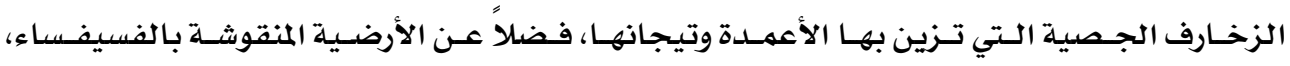

* أستاذ النسيج بقسهم تصميم الأزياء جامعة أم القرى

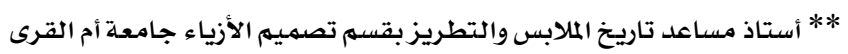




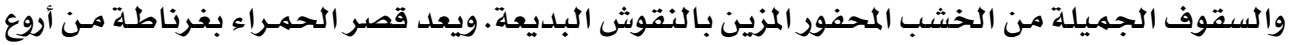

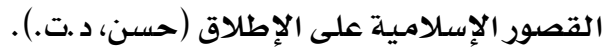

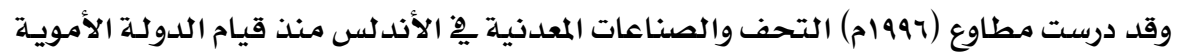

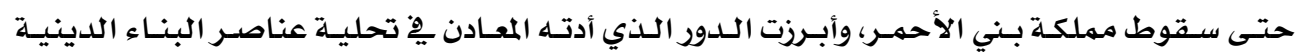
والمدنية والعسكرية.

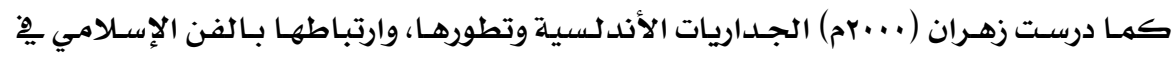

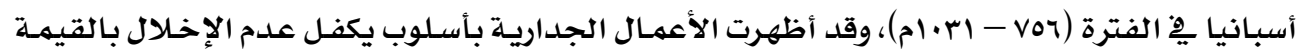

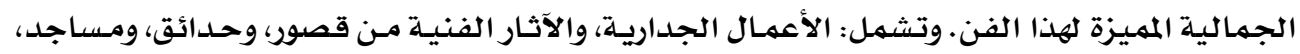

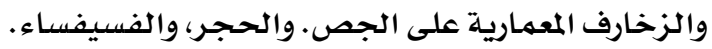

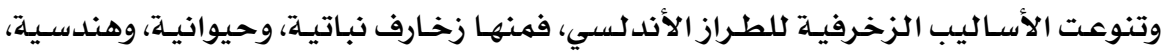

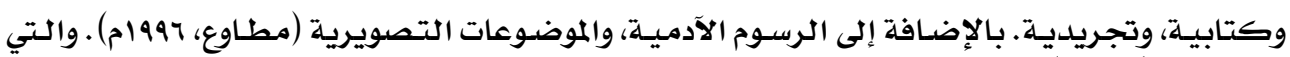

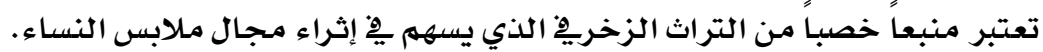

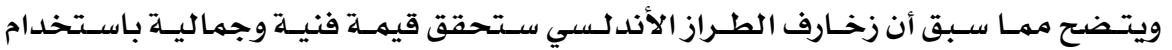

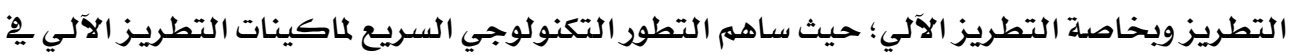

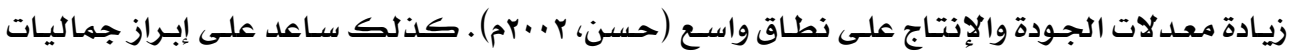

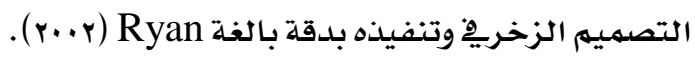

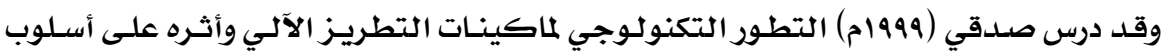

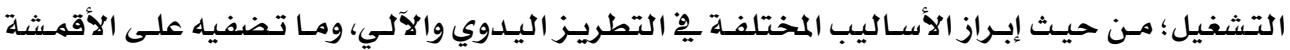

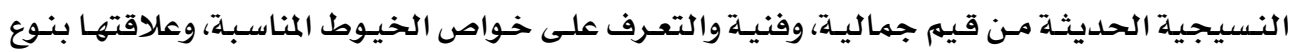

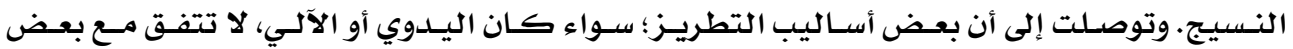
الخخامات النسيجية.

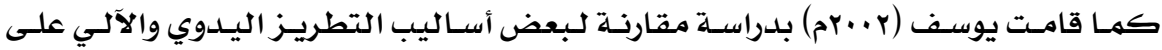

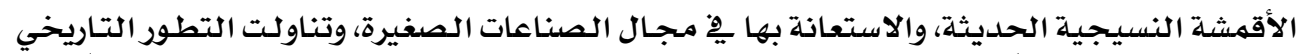

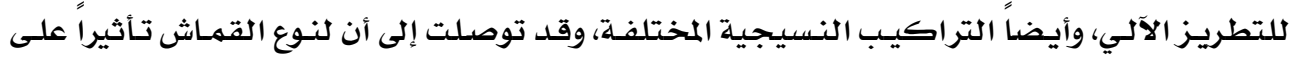
أسلوب التطريز، وكذلك الخيط المستخدم فِ التطريز.

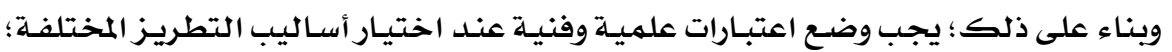

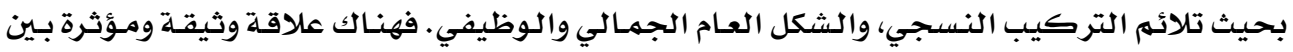

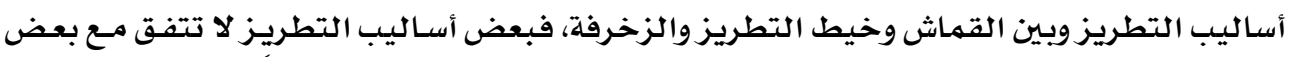

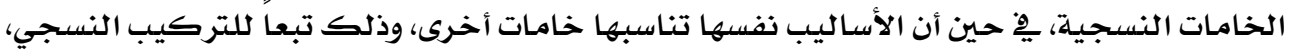
وملمس القماث ونوعه. 


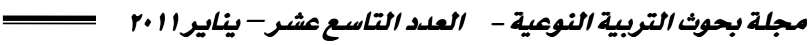

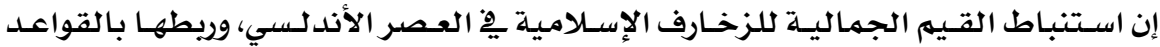

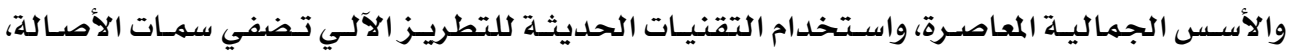

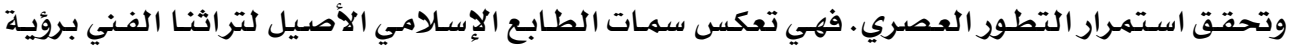
فنية معاصرة.

ومن هنا جاءت أهمية "دراسة زخارف الطراز الأندلسي وتوظيفها ِِّ إثراء الملابس باستخدام التطريز الآلي".

\section{هشكلة الدراسة:}

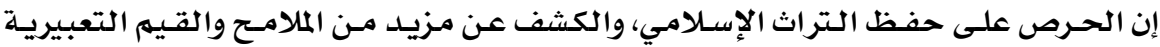

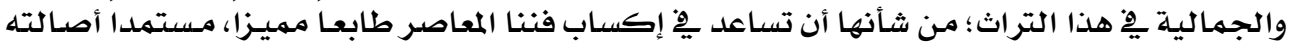

$$
\text { من الفن الإسلامي. }
$$

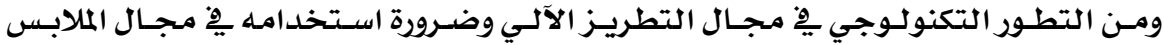

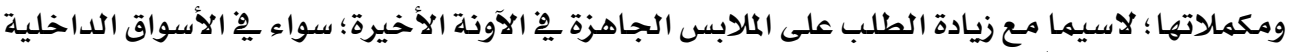

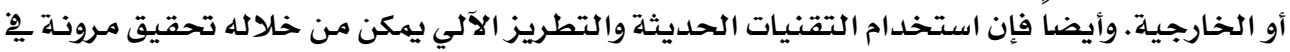

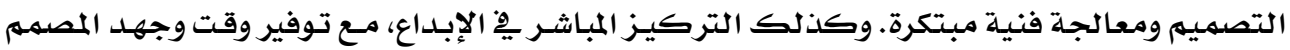

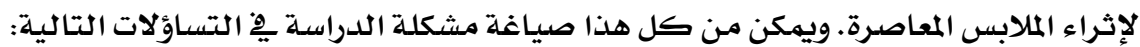

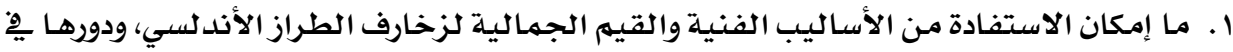

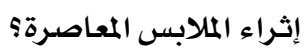

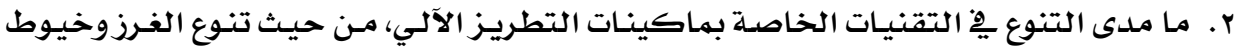
التطريز: ألوانها، وأنواعها؟

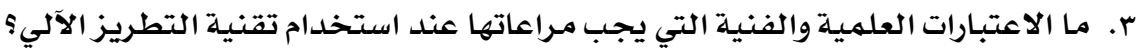

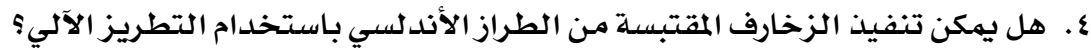

\section{أهميسة الدراسة:}

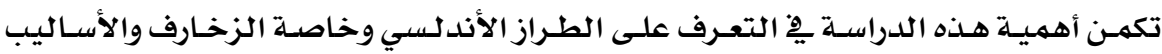

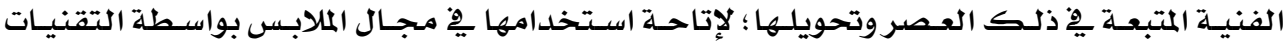

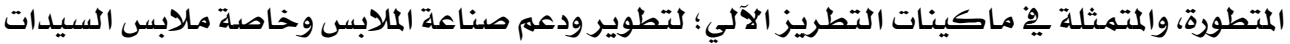

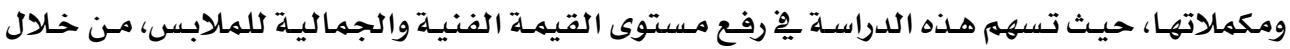

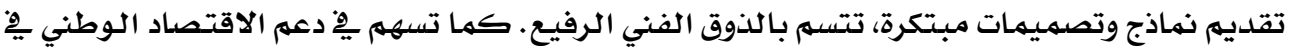

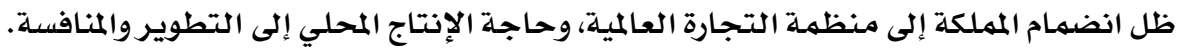

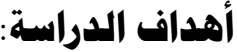

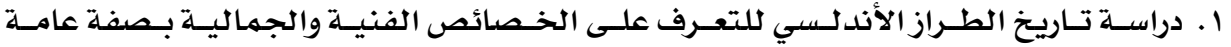


r. إبراز القيم الجمالية للأساليب الفنية المتبعة هِّ توزيع وتنفيذ زخارف الطراز الأندلسي.

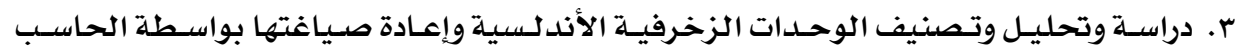

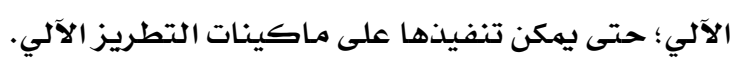

ع. التعرف على التقنيات المختلفة الخاصة بماكينات التطريز الآلي، والأساليب العلمية والفنية

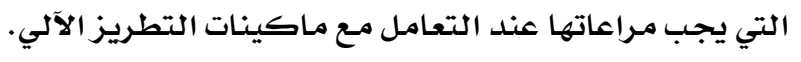

$$
\text { ه. تنفيذ الزخارف المقتبسة من الطراز الأندلسي باستخدام التطريز الآلي. }
$$

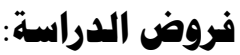

ا. تحليل مختارات من العناصر الزخرفية الإسـلامية للطراز الأندلسي يفيد يِّ معرفـة الأسساس

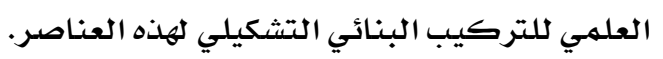

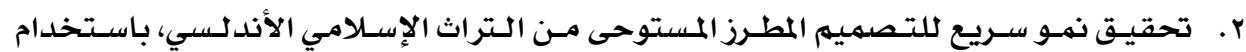

$$
\text { ماكينات التطريز الآلي وبرا مجسهـ }
$$

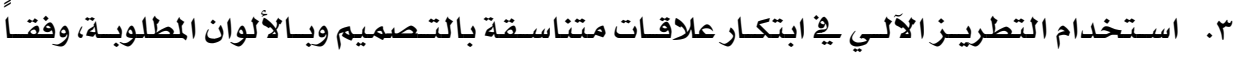

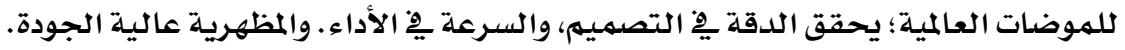

\section{هنهج الدراسة: - من}

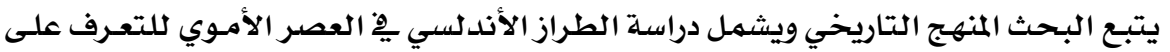

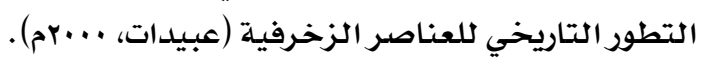

كهما يتبع المنهج الوصفي التحليلي حيث يشمل وصف العناصر الزخرفية من حيث أنواعها

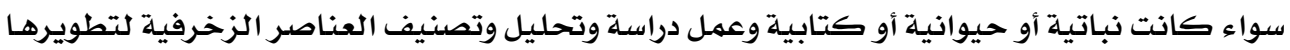

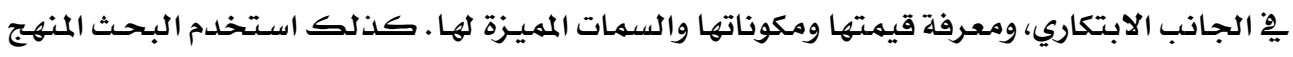

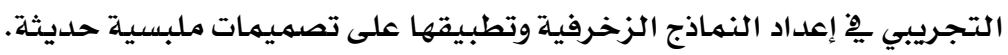

حدود الدراسة:

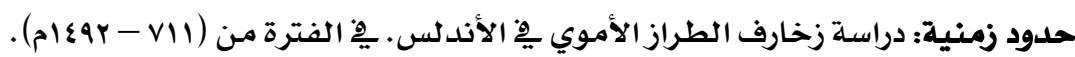

أدوات الدراسة:

$$
\text { أ- ماكينات التطريز الآلي: }
$$

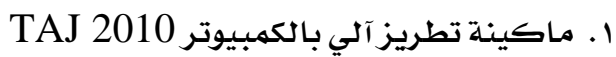

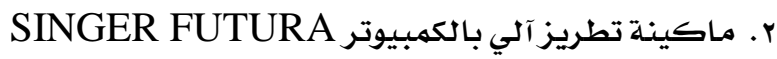

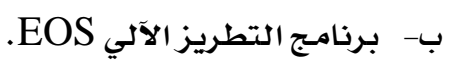

ج- الخامات المختلفة (الأقمشة - الكلف - الخيوط - فصوص الكريستال) المستخدمة يِّ تنفيذ الجزء التطبيقي. 
د- آلة التصوير الرقمية (الديجتال). هـ- الحاسب الآلي.

همطاتحات الدراسة:

Andalusia الأندلس:

المراد بلفـظ الأنــلس: أسـبانيا الإسـلامية بـصفة عامــة.وكـان يشمل شـبه جزيـرة أيبيريـا

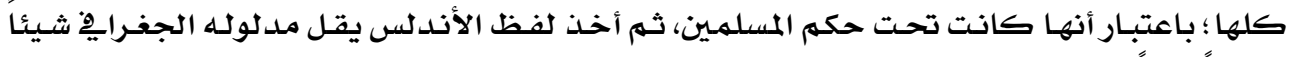

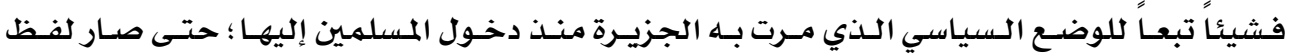

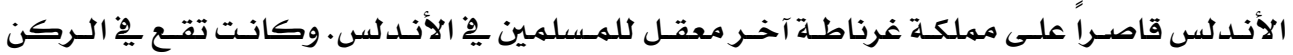

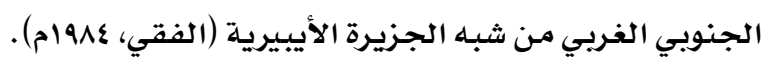

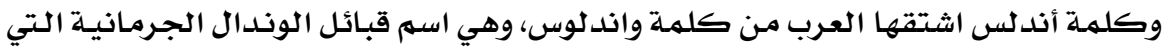

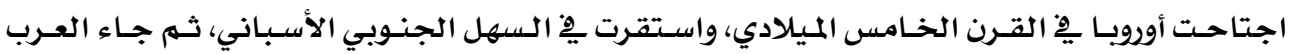

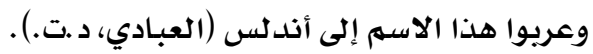

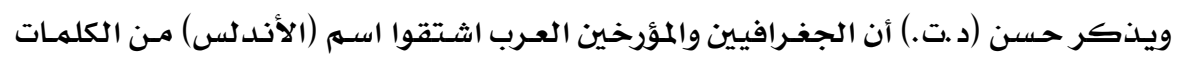

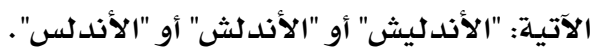

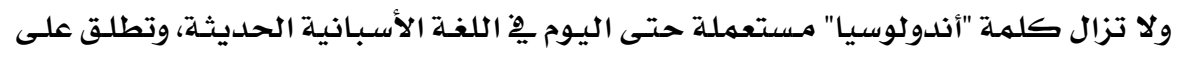

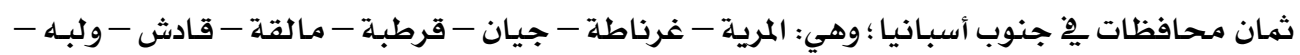

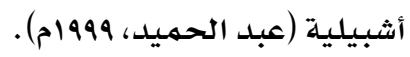

Andalusia Type •

اصطلح على تسمية الطرز الفنية الرئيسة منسوبة إلى الدول الإسلامية من أموية،، وعباسية

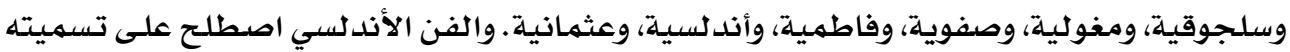

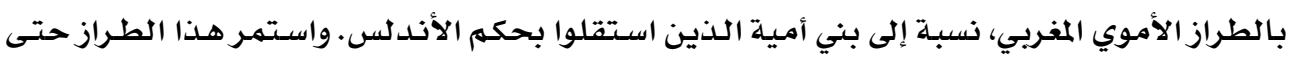

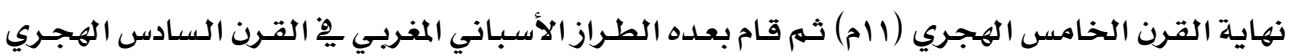

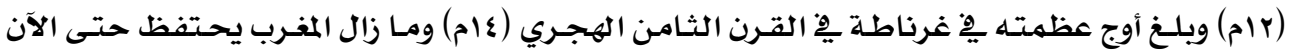

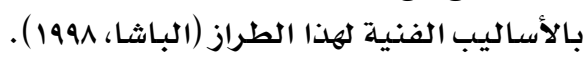

\section{الزخرفة Ornamentation}

"الزخـارف مـشتقة مـن الزخرفـة. وبـالرجوع إلى مـصـادرها وجـــ أنهـا تعـني: الزينـة، وكمـال

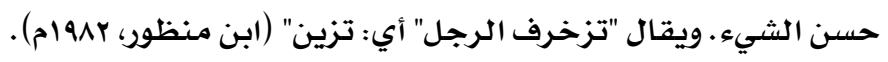

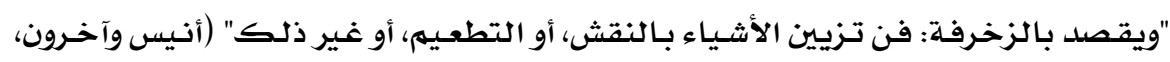
. (1994

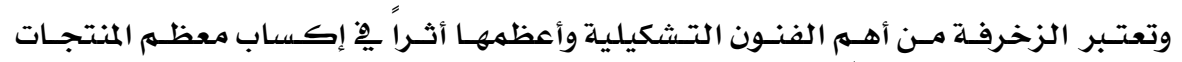

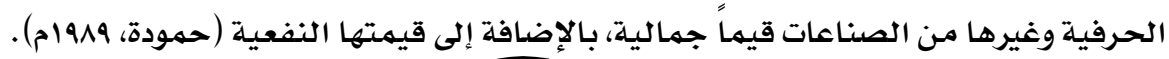


تقن: أتقن الأمـر: أحكمهـ. وهي الوسـائل التي تتخذ للنجاح يِّ أمـر ما، يختص بفـن أو بعلسم أو

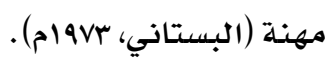
وهناك مـن يـرى التقنيـة يِّ مجـال الفـن بأنها : عبـارة عن طريقـة فنيـة؛ أي: الطريقـة المتبعـة

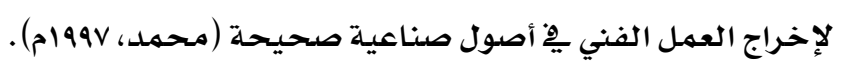

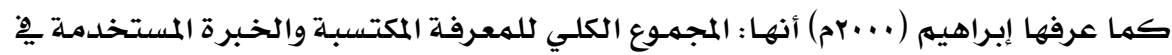
نطاق معين؛ من أجل إشباع حاجـة معينة تنصب يِّ النهاية على الدراية الفنيلة.

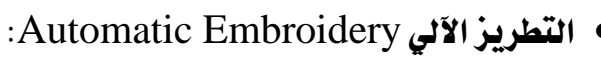

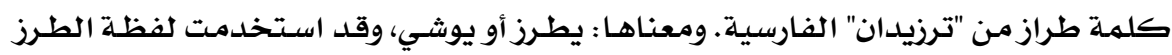

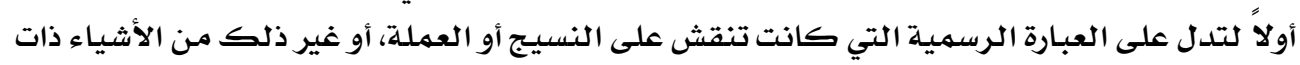

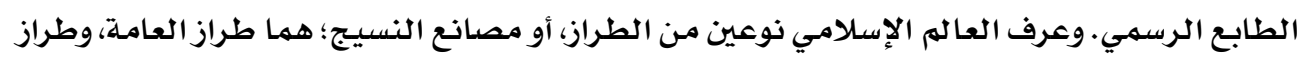

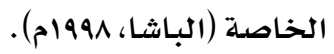
والتطريز الآلي عبارة عن زخرفة النسيج بعد أن يتم نسجه بواسطة الإبر الخاصدة بالتطريز،

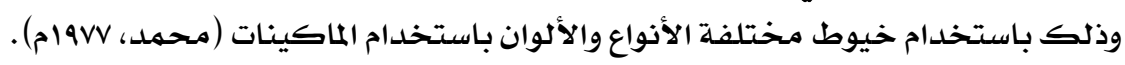

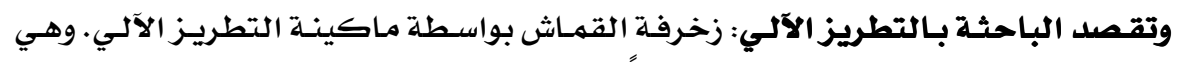

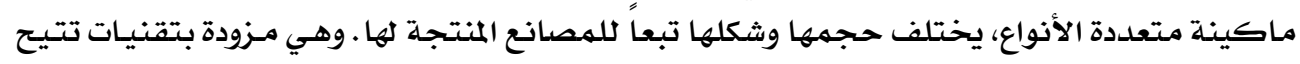

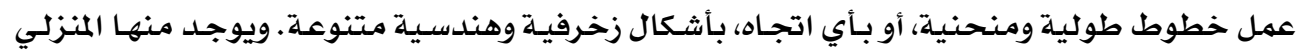

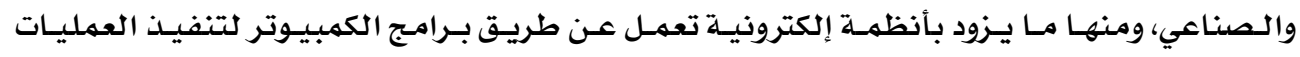

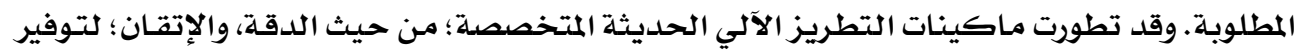

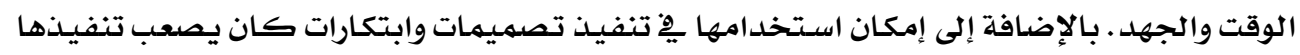
من قبل. • • أثرى : كثر ماله، والأرض: كثر ثراها، ويقال : أثرى مـا بـين الرجلين: تـاوما على الصلية .

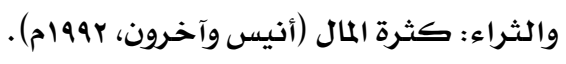

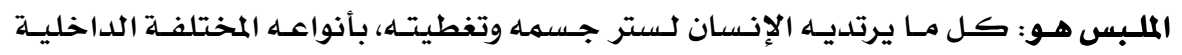

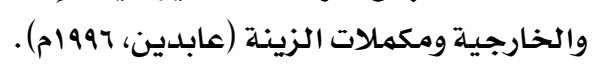

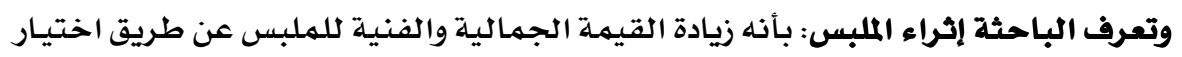

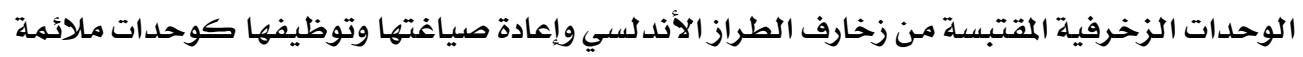

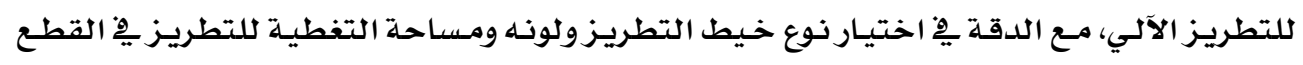

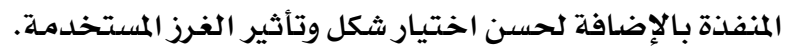




\section{الإطار النظري للدراسة:

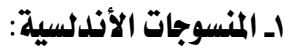

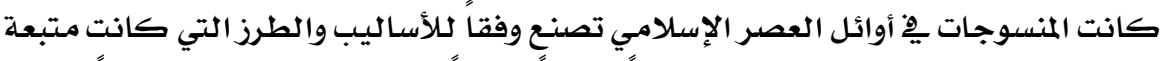

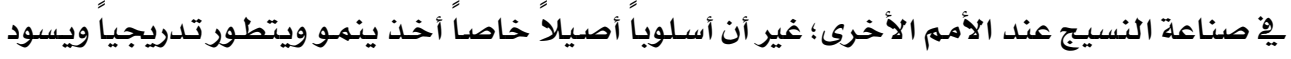

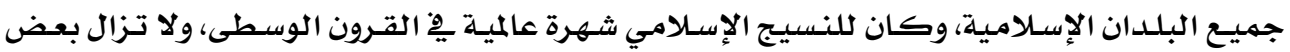

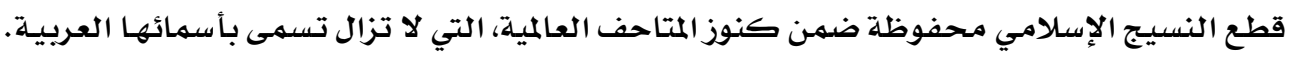

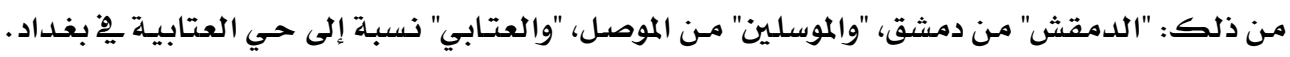

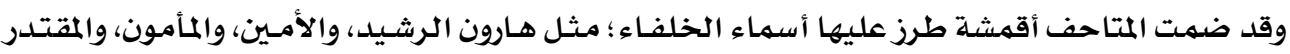

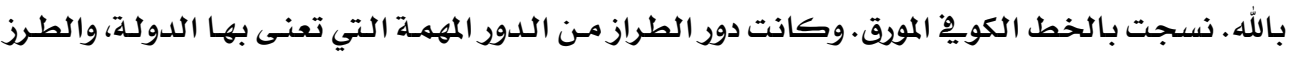

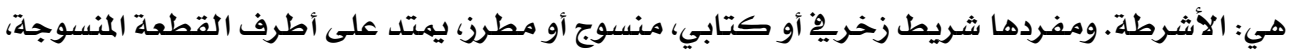

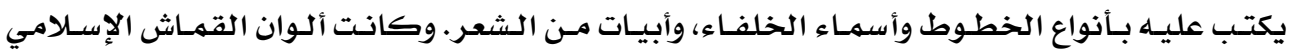

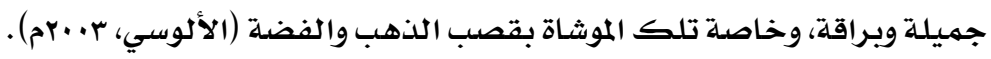

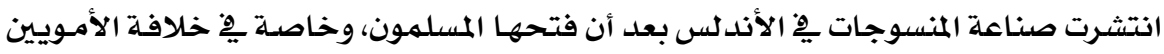

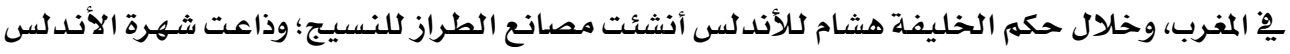

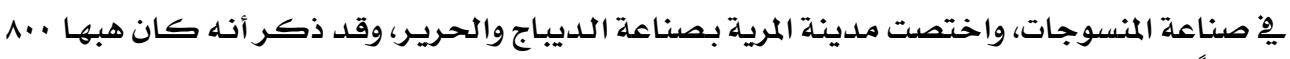

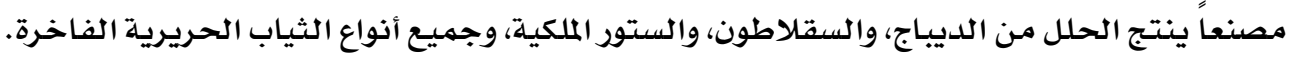

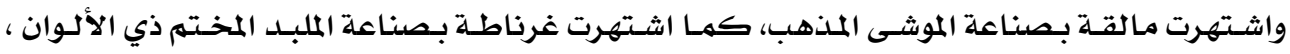

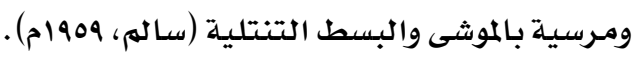

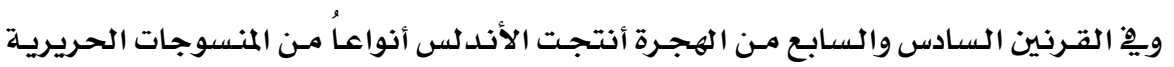

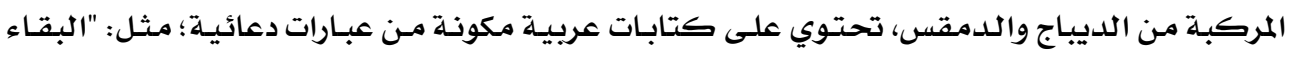

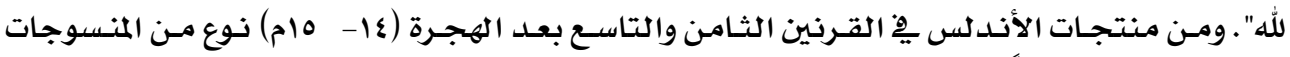

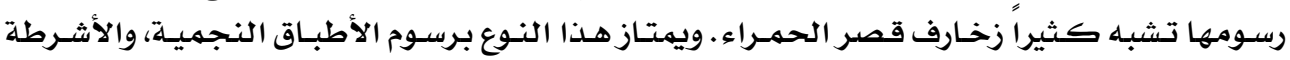

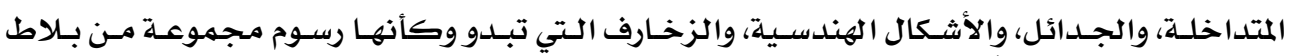

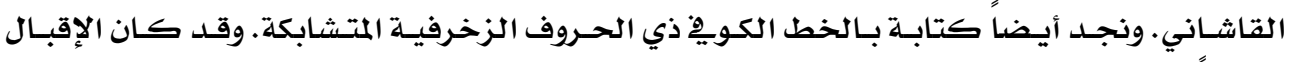

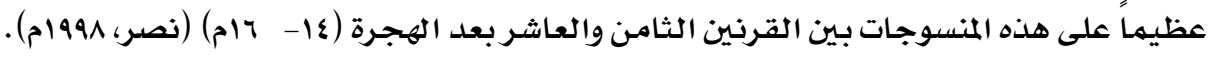

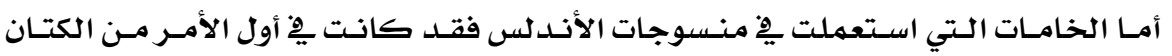

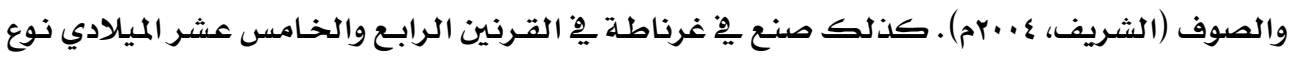

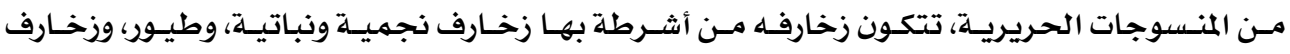

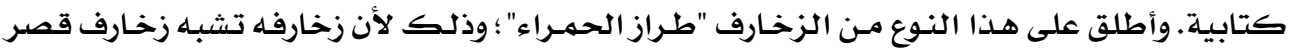

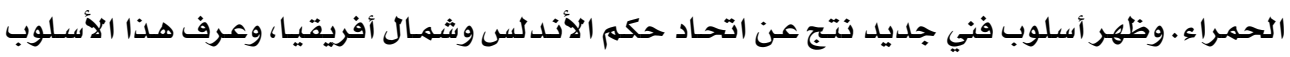

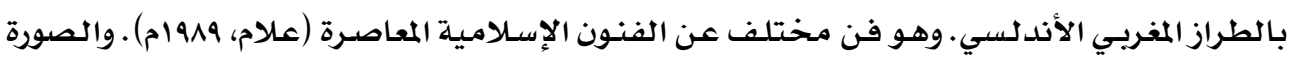


(1) توضح قطعة من النسيج صنعت من الحرير الموشى، تتكون زخارفها من أشـرطة بها زخـارف نجميـة

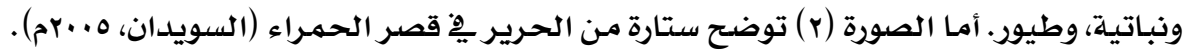

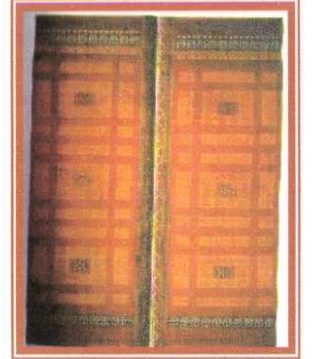

صورة (r) (r) (r) (1)

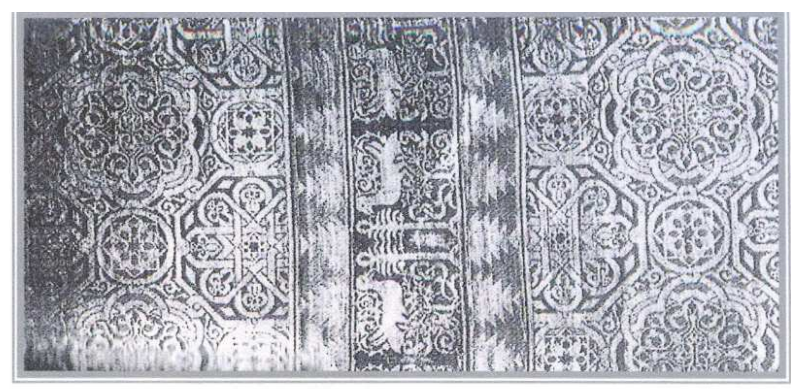

صورة (1)

$$
\begin{aligned}
& \text { الصورة (1) نسيج من الحرير الموشى، صناعة غرناطة ق ^هـ - عام (علام، و19 1م) }
\end{aligned}
$$

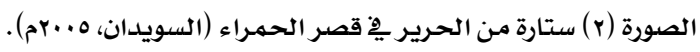

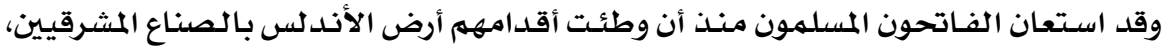

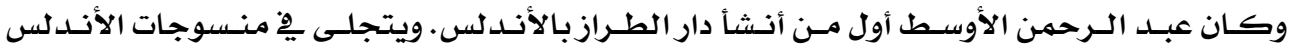

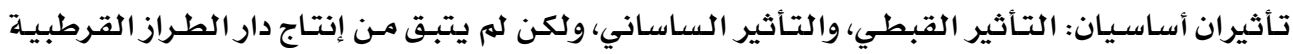

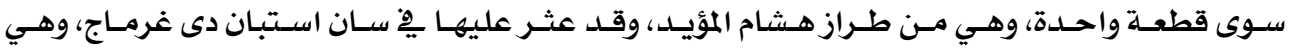

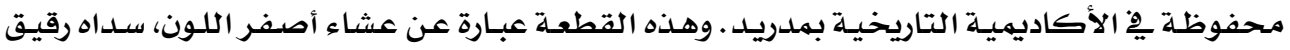

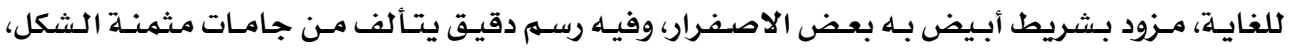

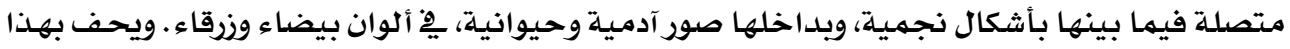

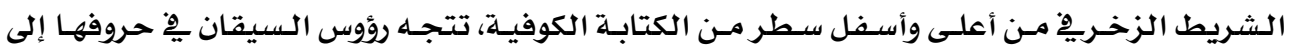

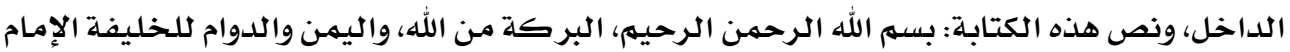

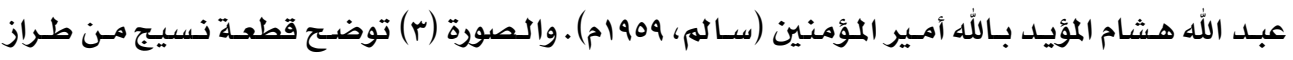
هشام المؤيلد.

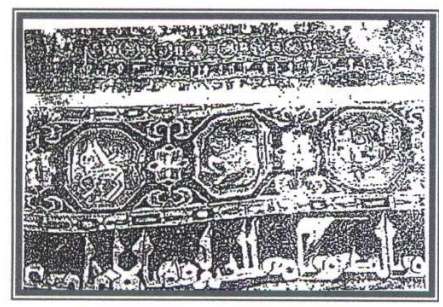

$$
\text { صورة (r) نسيج قباطي ق ؛ هـ من طراز هشام المؤيد (الشريف، ؟ . بrم) }
$$




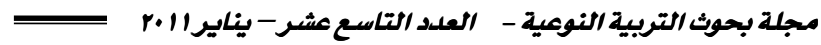

كذلك وجـدت قطعـة مـن الحـريـر تزينها زخـارف لأزواج مـن الحيوانـات المتدابرة فِ جامـات دائريـة (علام، 1919 م) .وتظهر مِّه الصورة (ع ).

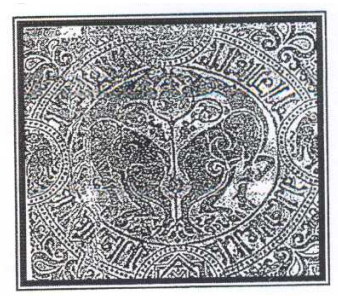

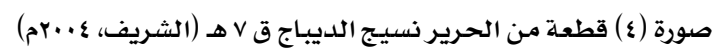

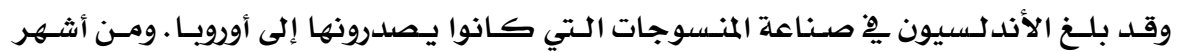

المنسوجات التي أقبل الأوروبيون على اقتنائها ذلك النوع الرقيق المعروف بـاسهم - غرنادين - نسبـة إلى غرناطة، التي كانت مركز صناعته (البـاشا، 19991م).

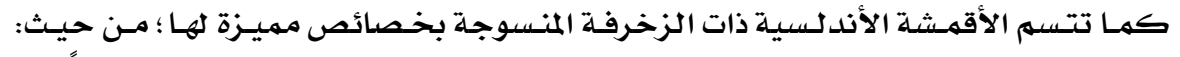

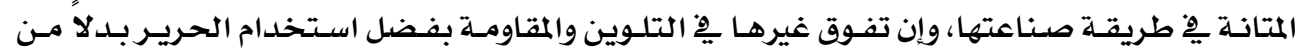

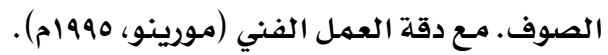

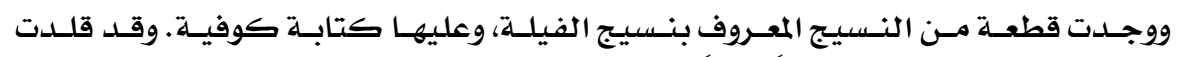

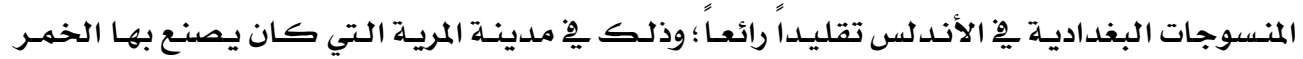
العتابية - وهي أقمشة تغطي بها النساء رؤوسهن - والأصبهانية والجرجانية (سالم، 1909 م) . والصورة (0) توضـح نسيـج الفيلـة، وبـه صـورة فيـل واحسد داخـل جـامسة، تحـف بها زخرفـة مـضفورة، ويعلـو الفيـل شـرة.

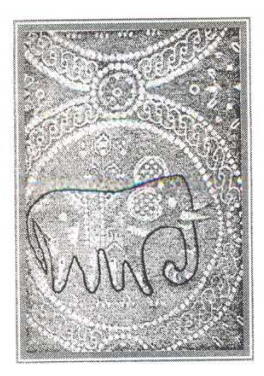

$$
\text { صورة (0) نسيج الفيلة (سالم، 1909 م) }
$$

وتحتفظ كنـيسـة سـان سبـاستيـان دي انتقيرة بحلسة دينيـة، قبـل إنها صسنعت مـن علسم، غنهها

المسيحيون مـن الجـيث الإسـلامسي الغرناطي. وزخرفتهـا تتـألف مـن منـاطق ذهبيـة على أرضـيـة حمـراء وخضراء كذلك من القطع الحريرية التي تنسب صناعتها إلى الأندلس فِ القرن بام قطعة مزخرفة 
بأزواج من الطواويس والحيوانات المتقابلة، تتقابل على شجرة الحياة (علام، 919 1م) .وتظهر بِّ الصورة

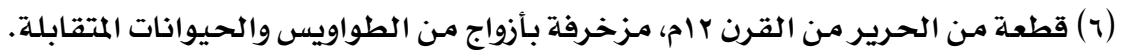

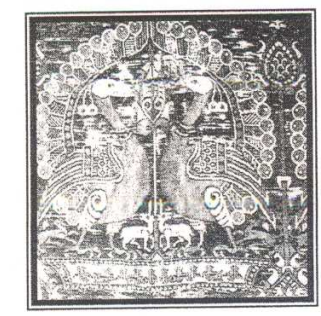

وقد تحولت صناعة المنسوجات ذات الصور الحيوانيـة يِّ عصر الموحسدين إلى منسوجات ذات

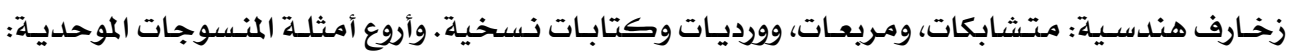

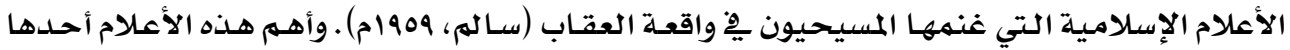

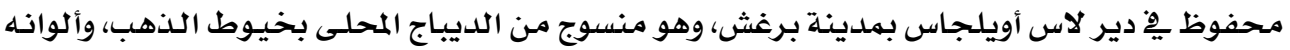

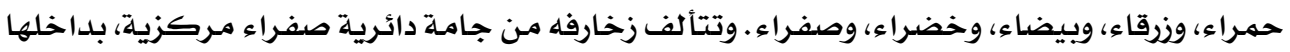

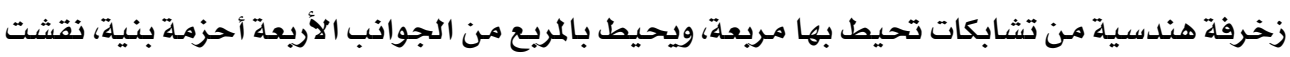

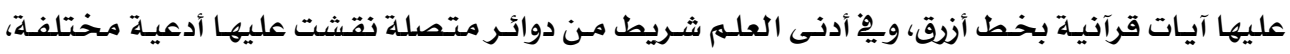

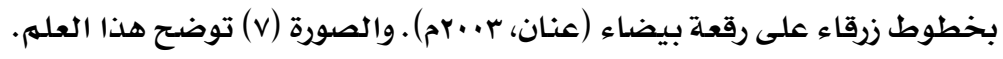

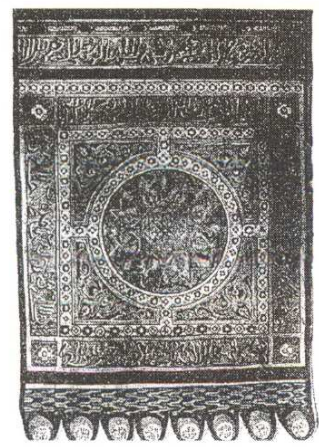

صورة (v) العلم الإسلامي الموحدي الذي غنمه النصارى بِّ موقعهة العقاب. (عدنان، ب. بrم)

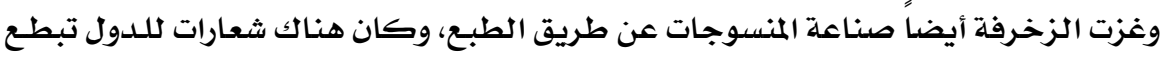

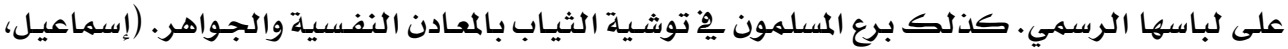
. (199r

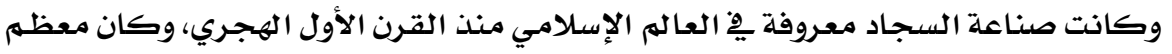

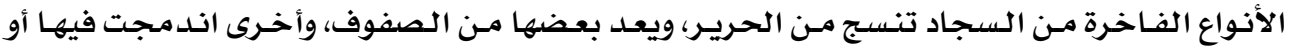

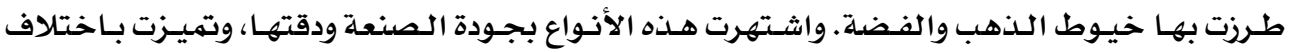

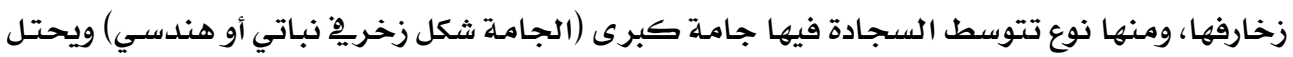


كل ركن من أركانه ريع جامـة، ويحيط بها إطار عريض وتنتشر عليها الأزهـار بـين تفريعات نباتيـة،

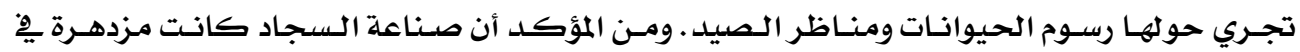

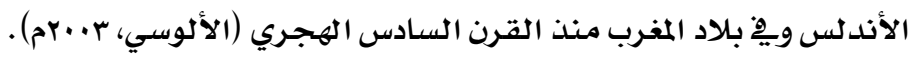

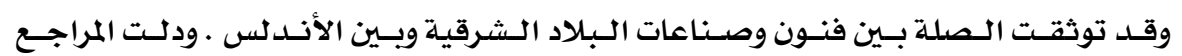

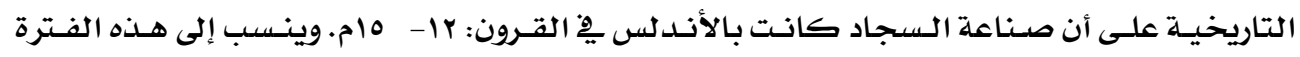

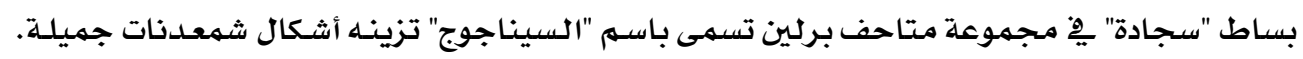

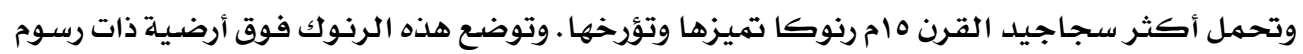

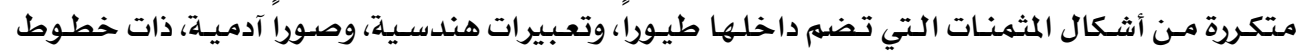

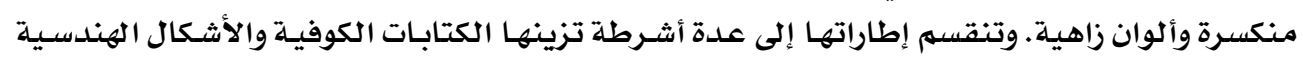

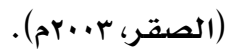

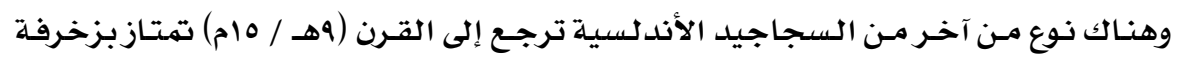

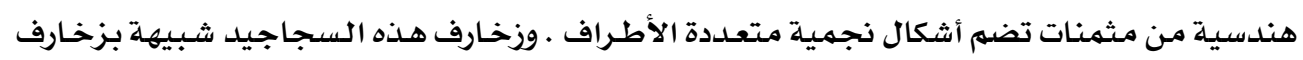

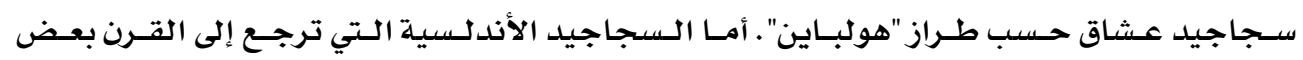

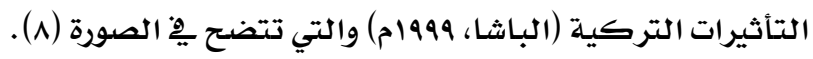

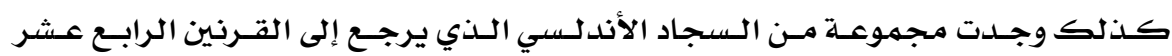

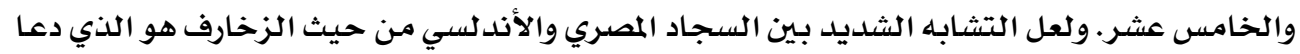

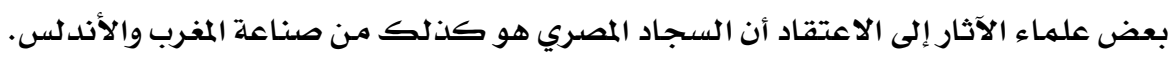

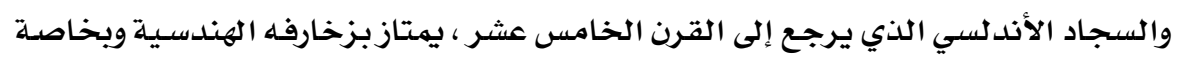

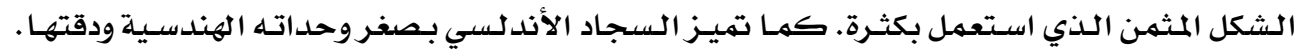

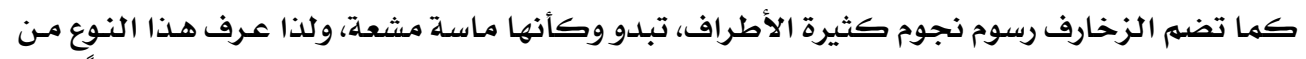

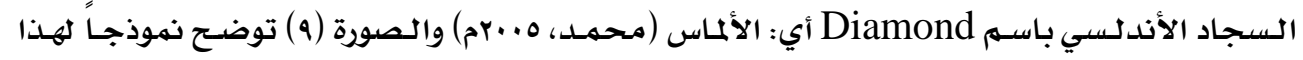

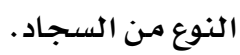

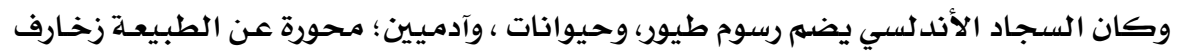

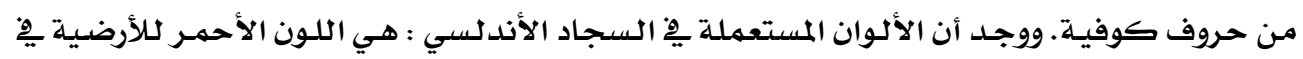

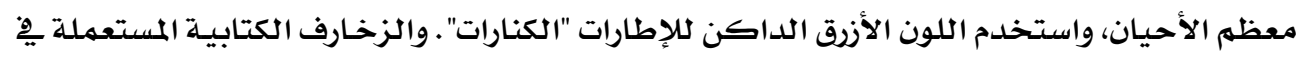

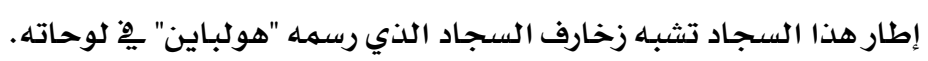

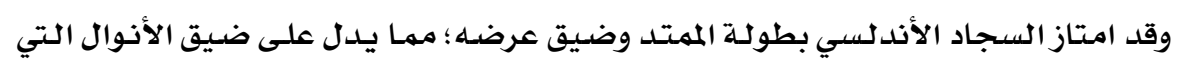

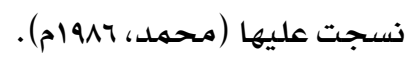



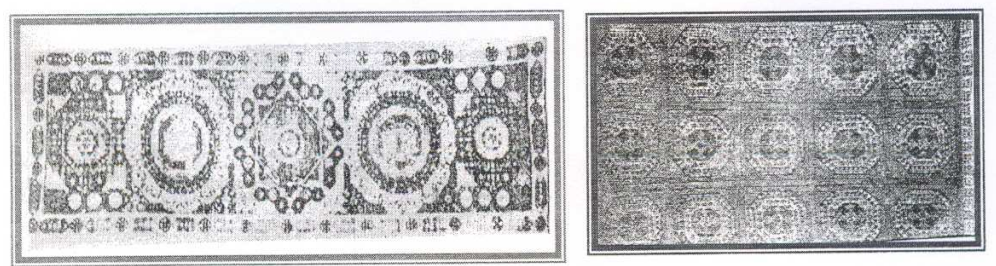

صورة (^) سجادة من الأندلس بها زخارف هندسية متكررة ، ق وهـ - ام (علام، و919 م)

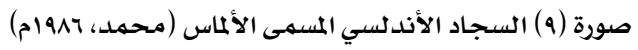

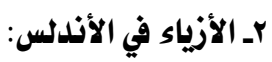

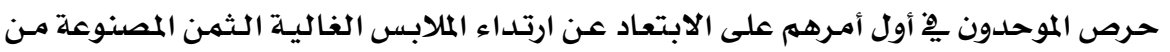

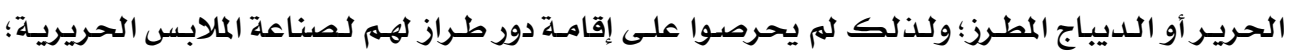

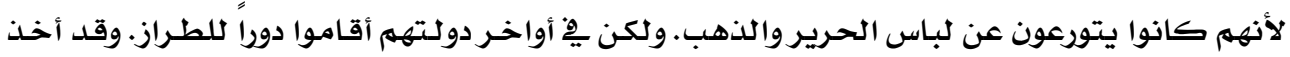

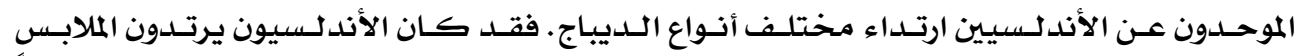

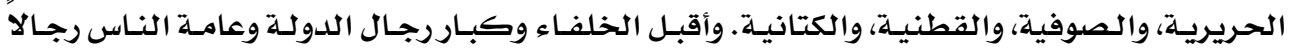

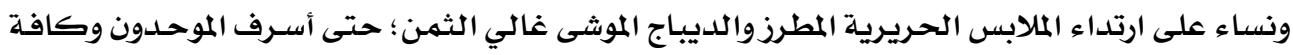

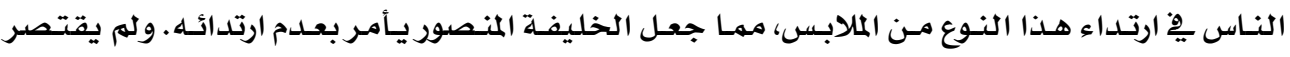

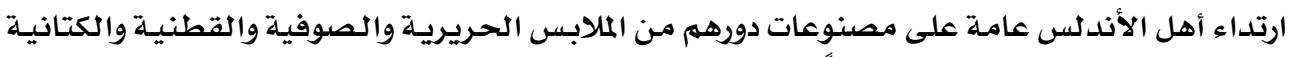

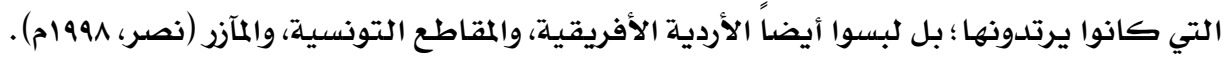

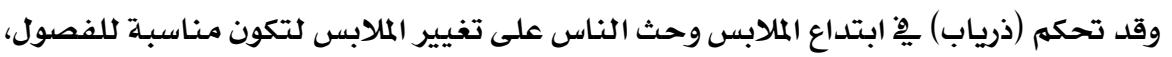

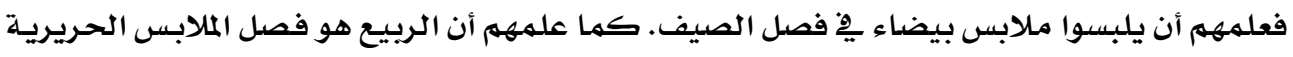

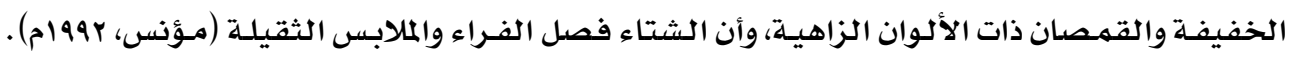

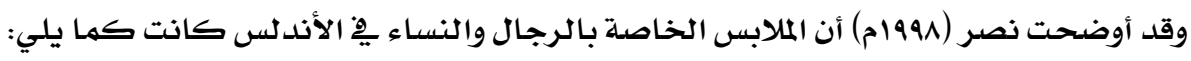

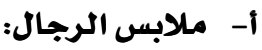

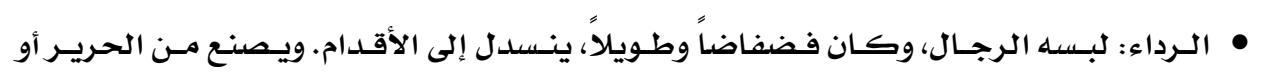
القطن أو الكتان.

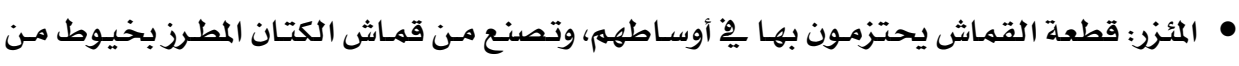
الحرير المذهب، وكانت تسهى أسفاقس.

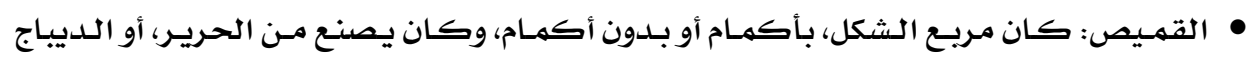

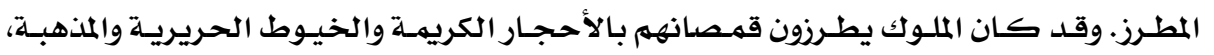

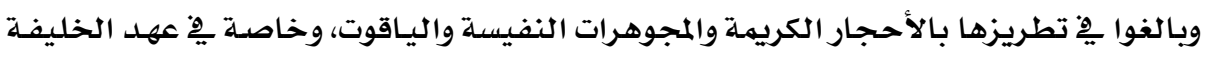
الناصر. وقد استخدموا القمصان الحريريـة ذات الألوان الزاهية. 


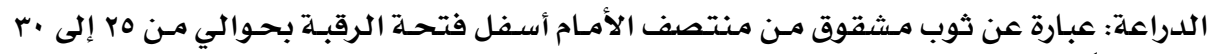

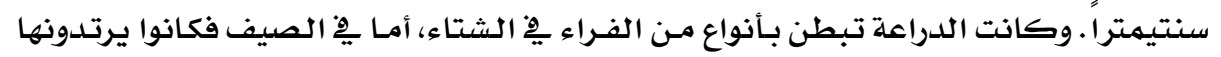
بلدون بطانة.

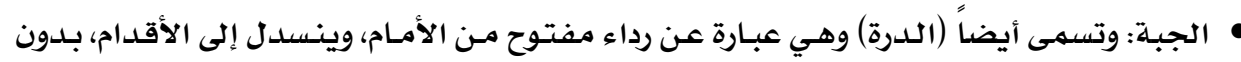

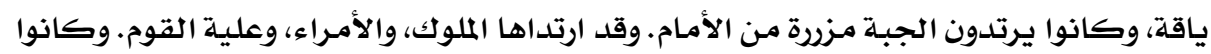

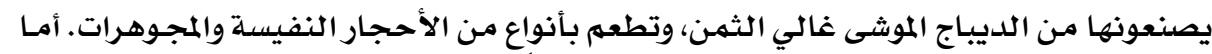

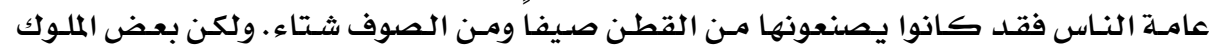

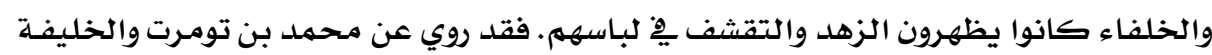

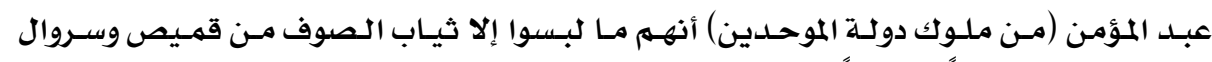

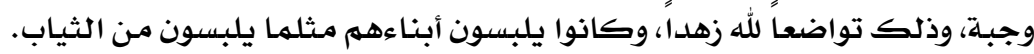

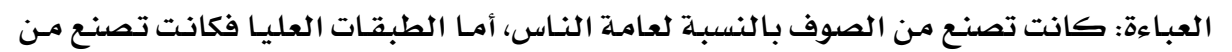

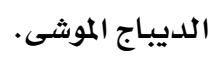

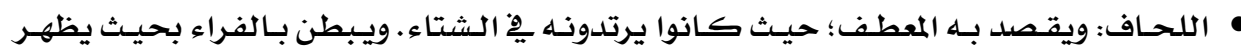
الفراء من أطراف المعطف وياقته وأكمامـهـ.

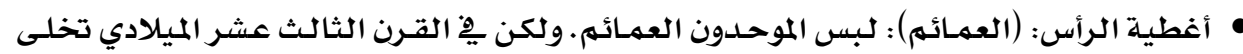

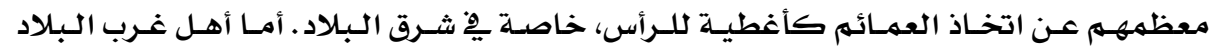

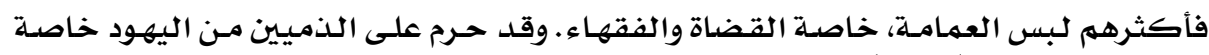

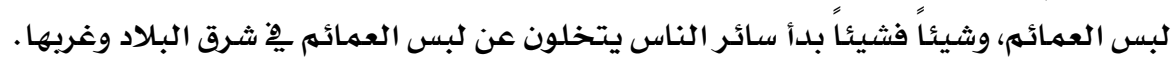
القبعـات: كانت تلبس فِ الشتاء خاصـة، وتصنع مـن فراء حيـوان يسـى القنليـة، وهو حيـوان أصغر من الأرنب، وأحسن وبراً منه.

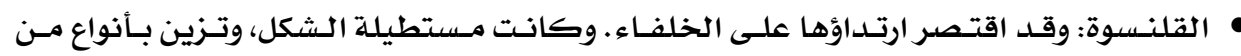

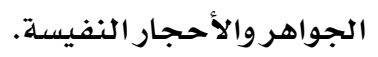

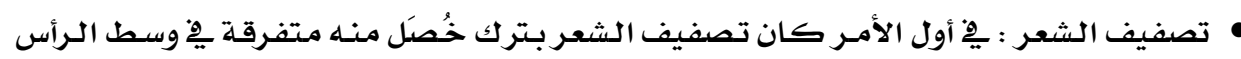

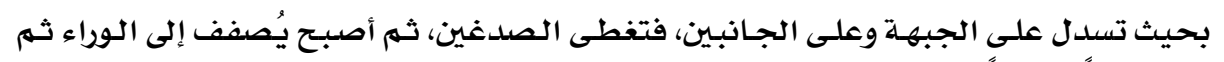

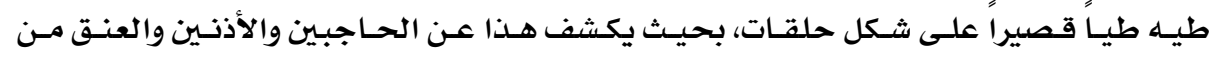
الخلف.

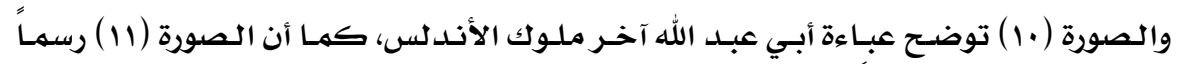

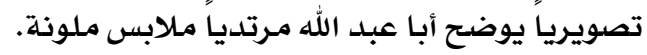



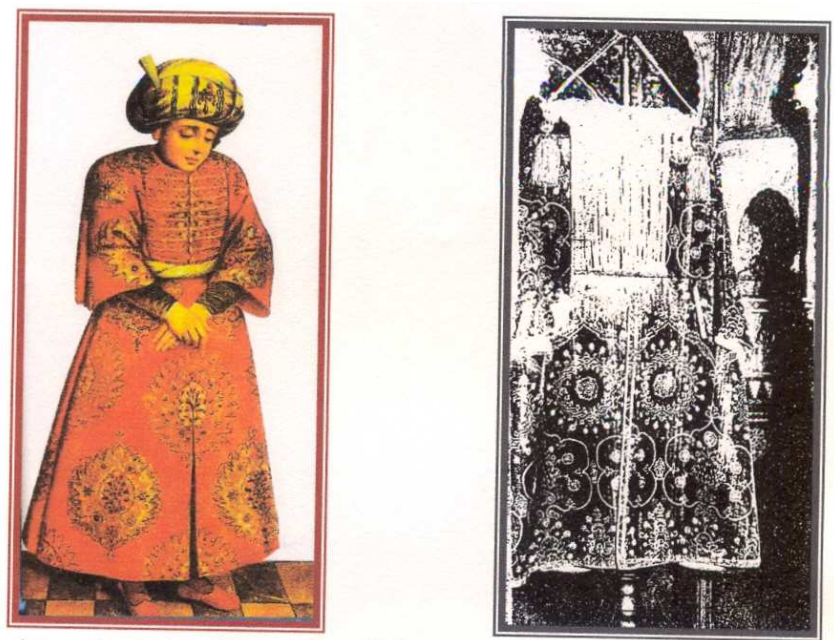

$$
\text { صورة ( •1) عباءة أبي عبد الله آخر ملوك الأندلس (عنان، ب..rمم) }
$$

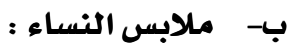

• القميص : كان يصنع مـن الحرير أو الديباج. • الثوب : كان واسعاً فضفاضنا، ويرتدي فوق القهـيص. وكانت المرأة ترتدي فوق الثوب حزامـاً

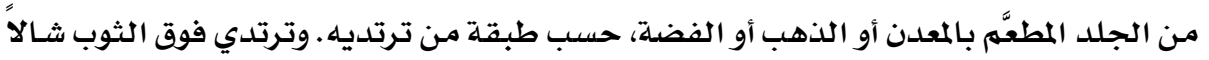
من الصوف المزخرف بزخارف متعددة.

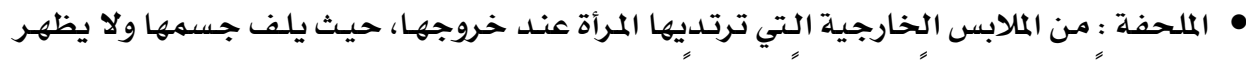

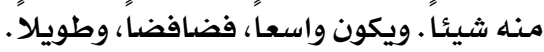
• البر نس : مـن أغطيـة الـرأس الـتي انتشرت عن طريـق الفتوحسات الإسـلامية، وقد اقتصر ارتــاء

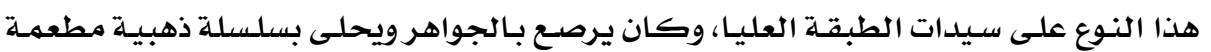
بالأحجار الكريمة. • الخمهار : وقد استخدمته النسـاء المسلمـات.

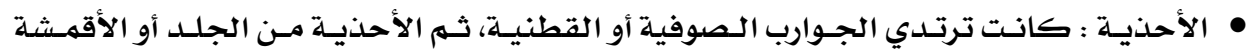
المطرزة.

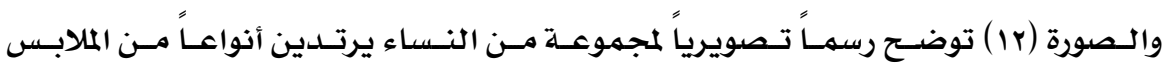
الأند لسيسة. 


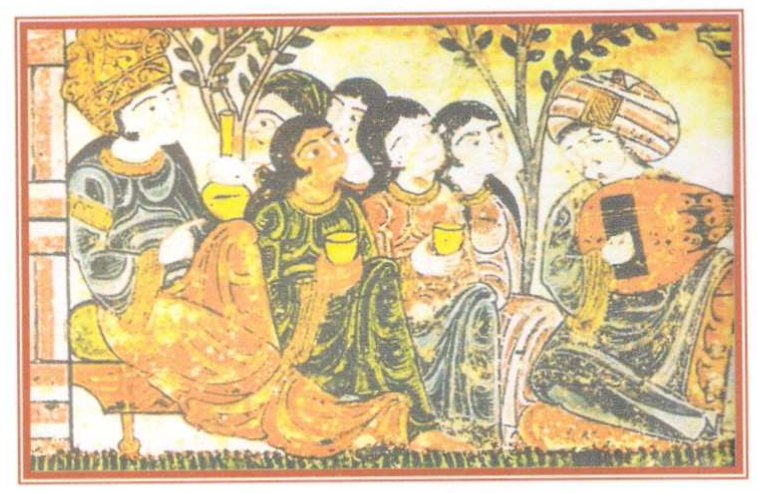

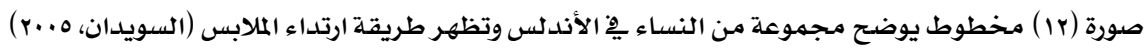

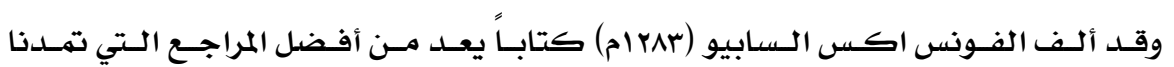

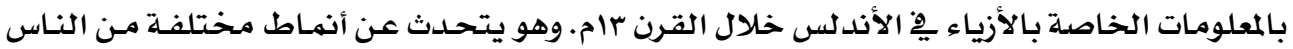

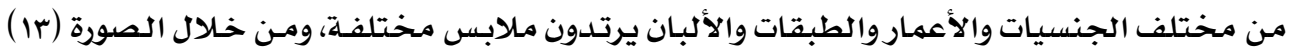

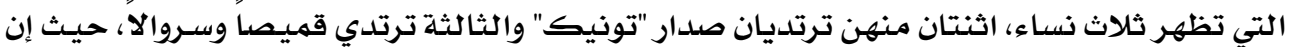

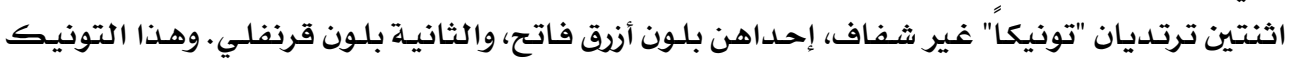

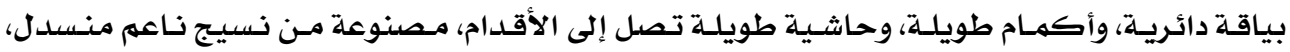

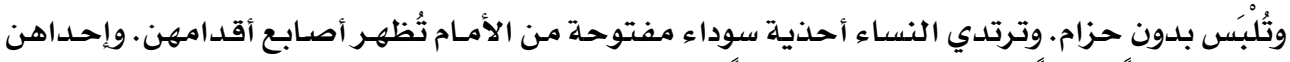

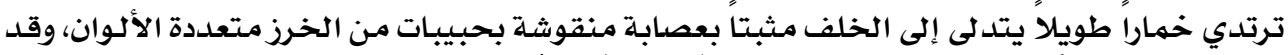

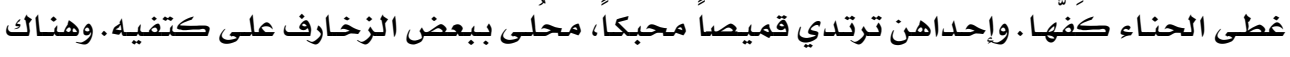

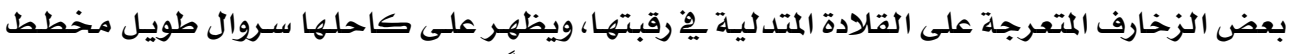

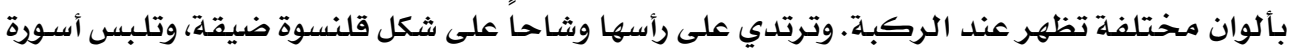

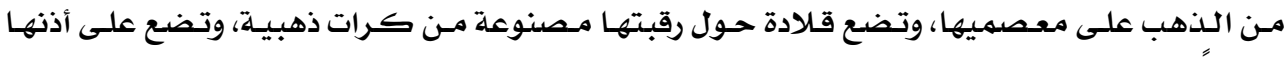

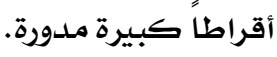

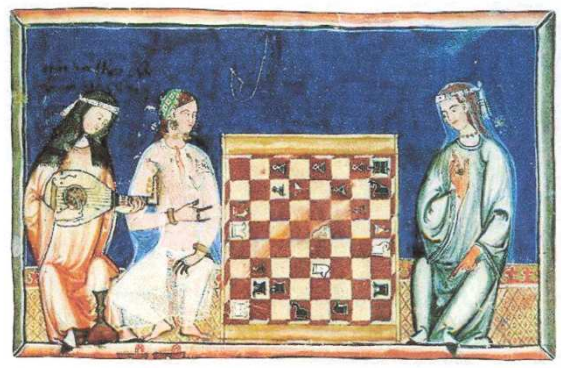

صورة (r) مخطوط يظهر مجموعة من النساء الأندلسيات يلعبن الشطرنج يرتدين ملابس متنوعة http://home.earthlink.net/ lilinah/costuming/andalus13c.html 


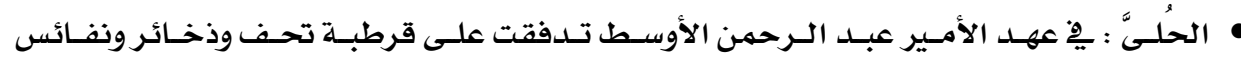

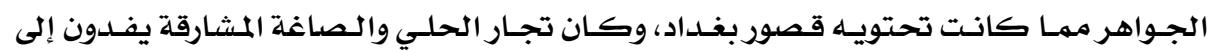

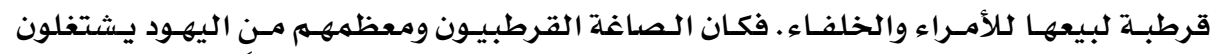

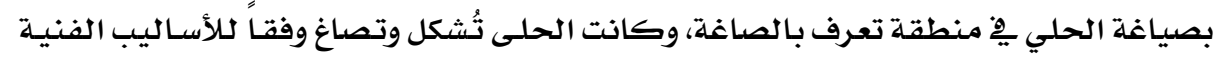

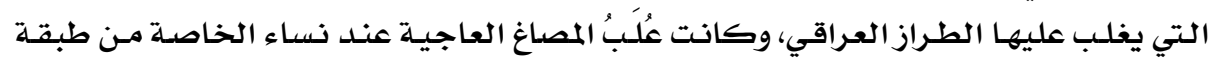

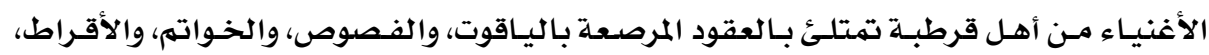

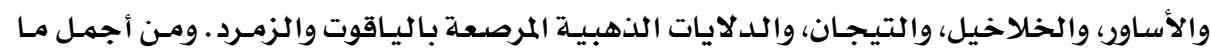

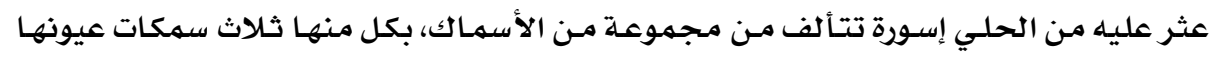

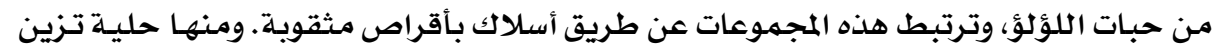

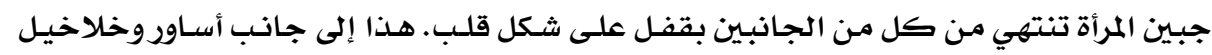

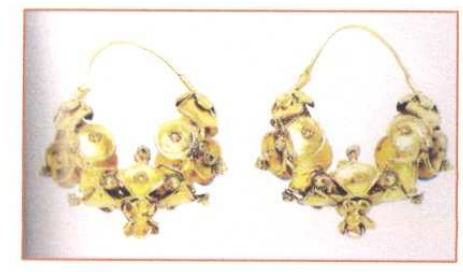

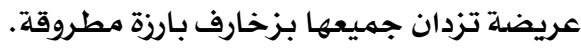
وصورة (£ ) لأقراط ذهبية تعود لحكم (مملكة الطوائف)

بـالوحدات الزخرفية بالطراز الأندلسي : تتميز الزخارف الإسلامية بالطراز الأندلسي بالثراء الفني، والصدق مِّه التعبير عن مشاعر

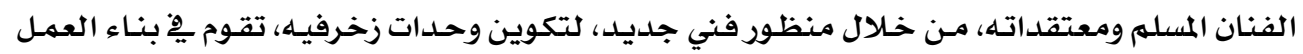

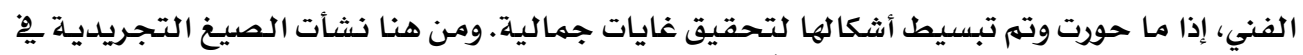

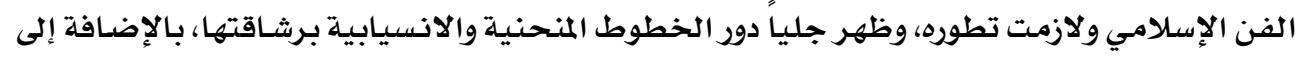

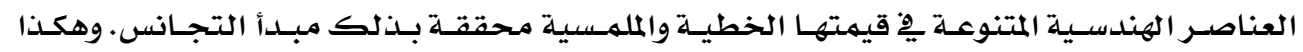

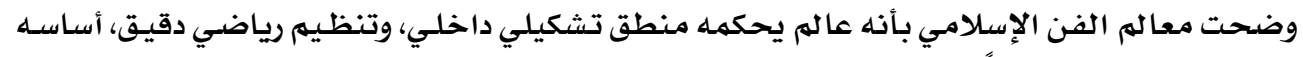

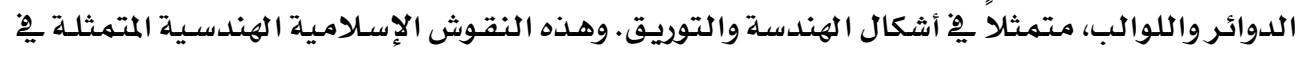

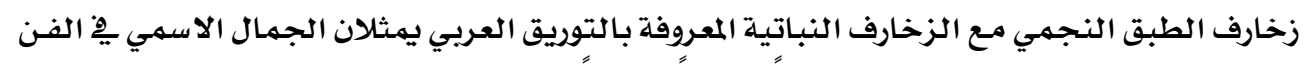
الإسلامي، الذي يدرك بالعقل والقلب معاً إدراكاً مباشراً.

\section{ويمكن تصنيف الوحدات الزخرفية هِّ الطراز الأندلسي إلى:}

أ- الوحدات الزخرفية النباتية:

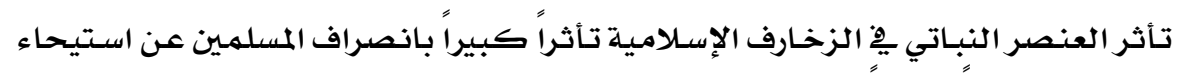

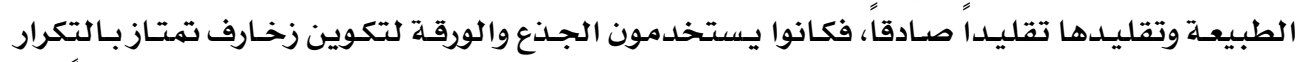

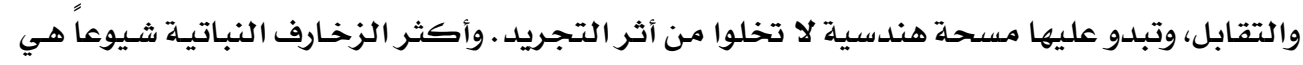

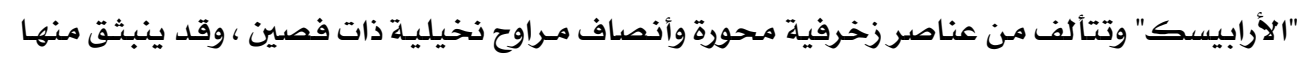




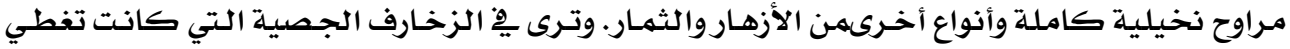

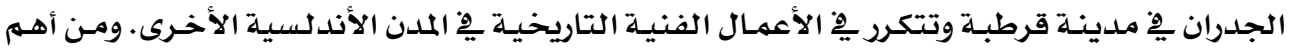

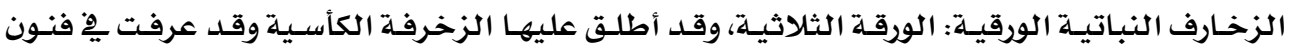

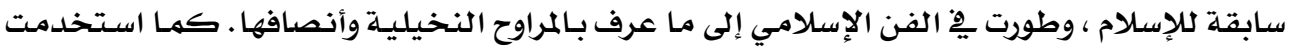

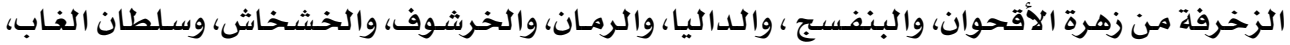

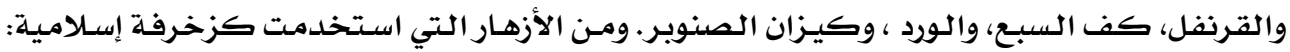

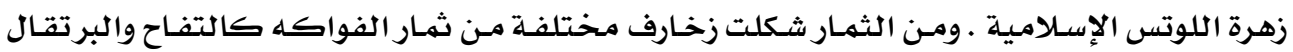

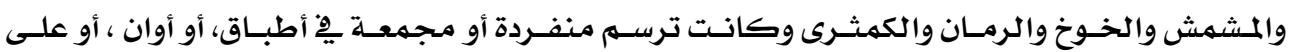

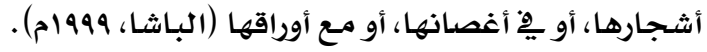
تأثرت الزخرفة النباتية يٌْ (عصر الخلافة) بالأسلوب الكلاسيكي، وسـاعد ذلك على ظهور

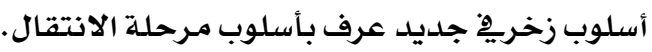
وبعد سقوط الخلافة الأموية بقرطبة تفككت الوحدة السياسية يِّ البلاد، واشتد الصراع بين

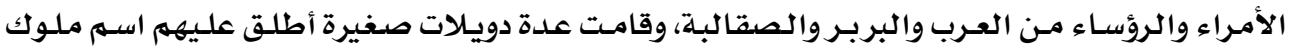

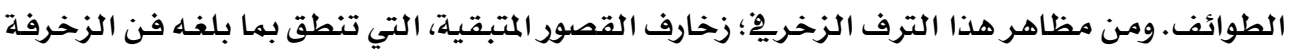

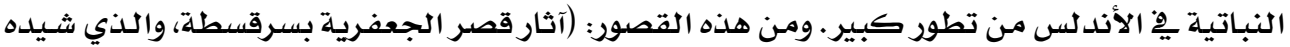

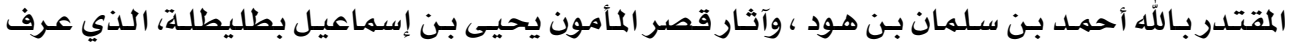

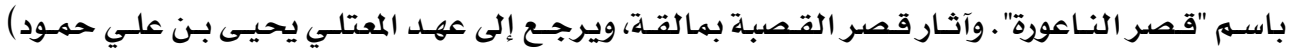

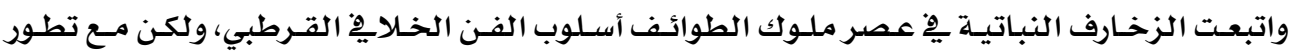

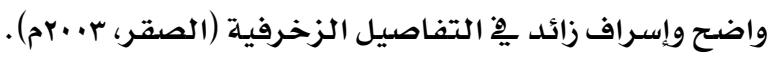

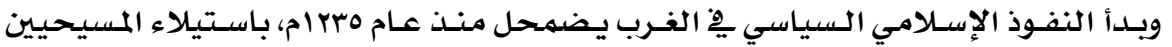

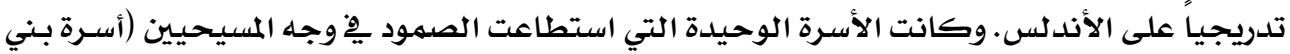

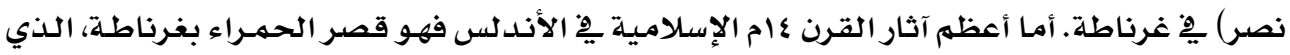

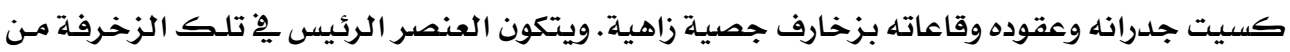

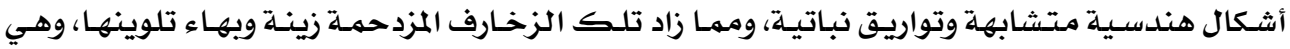

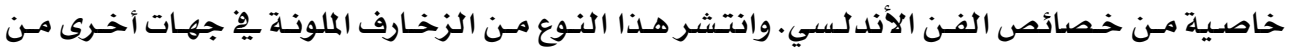
الأندلس.

\section{ب- الوحدات الزخرفية الحيوانية والآدمية:}

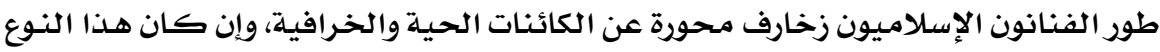

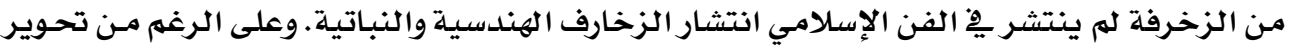

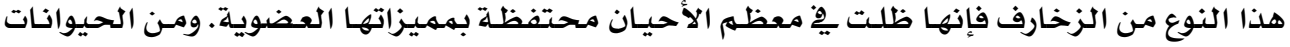

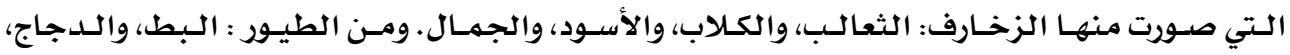

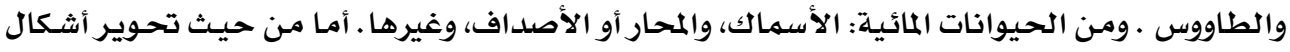




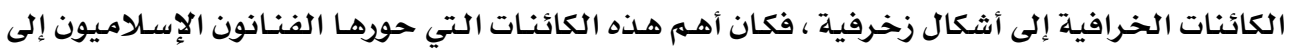

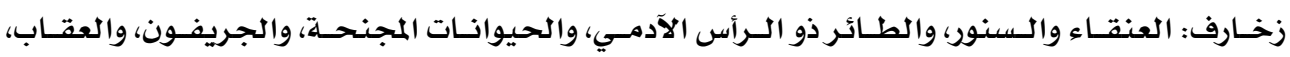

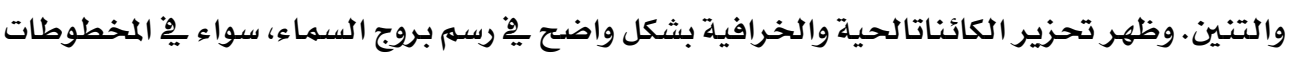
، أو على التحف، أو على المسكوكات، أو على التهئ العمائر.

ج- الوحدات الزخرفية الهندسية:

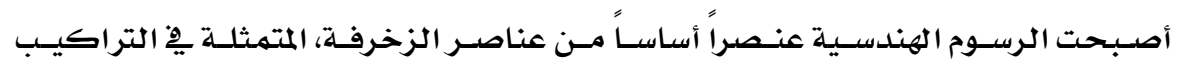

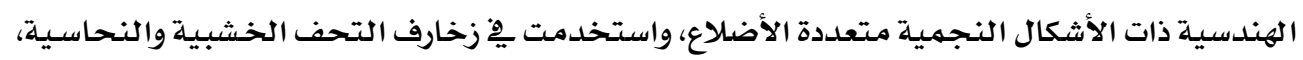

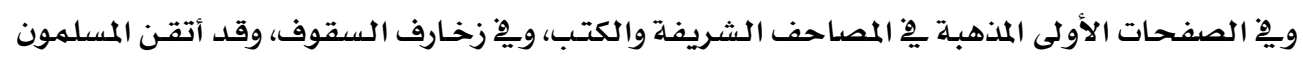

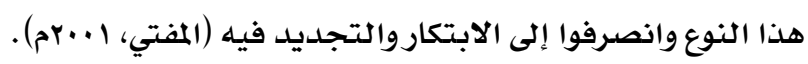

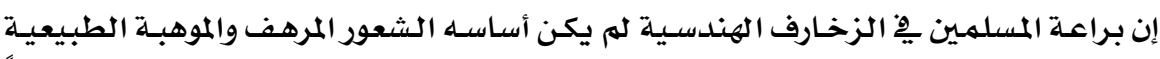

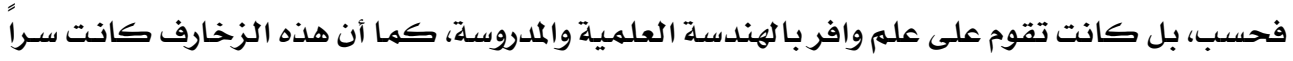

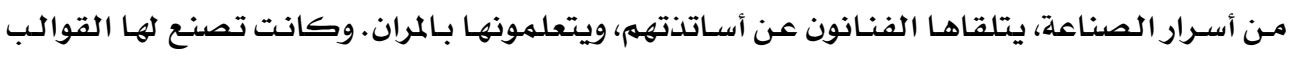

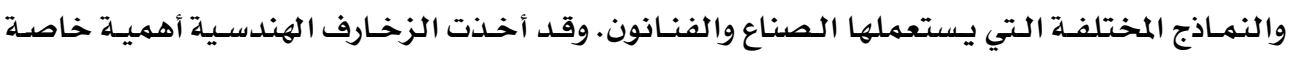

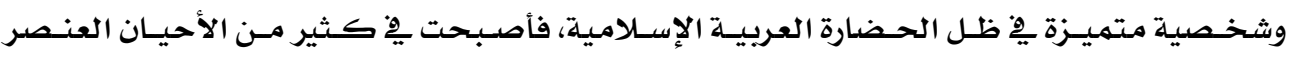

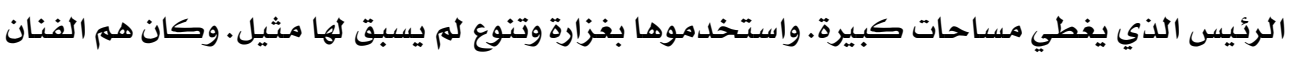

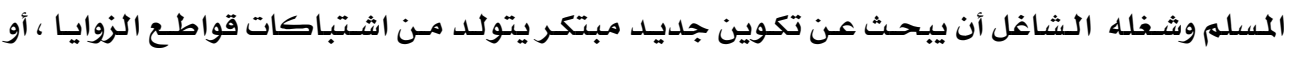

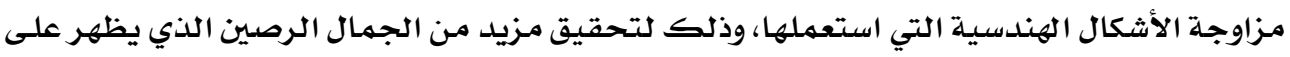

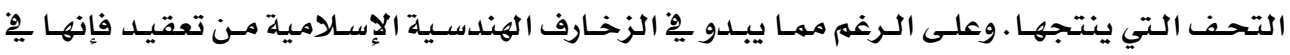

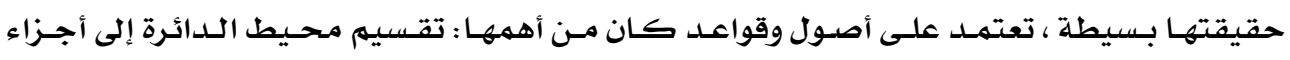

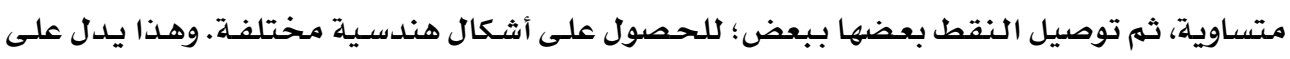

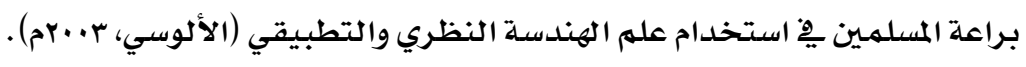

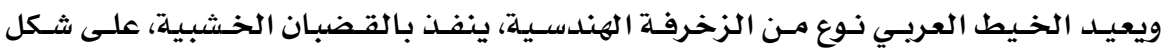

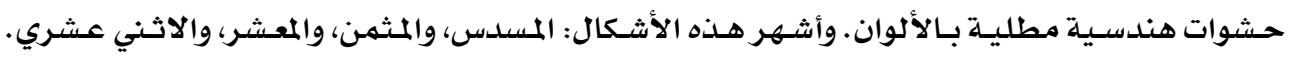

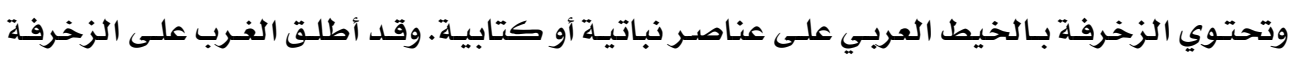

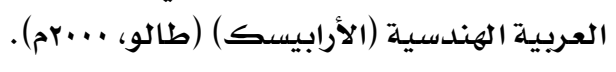

د- الوحدات الزخرفية الكتابية:

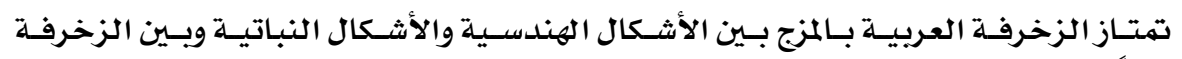

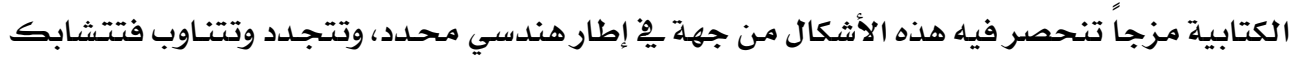

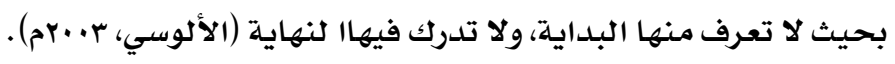

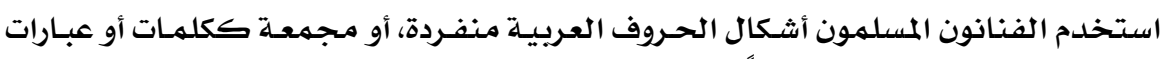

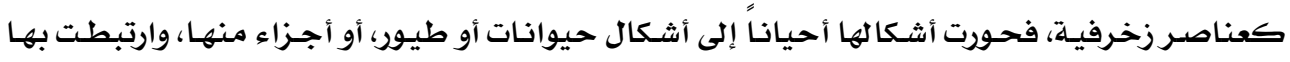




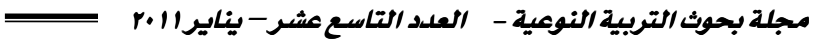

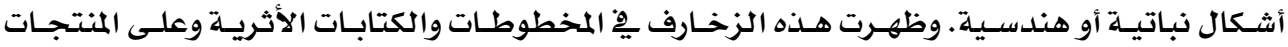

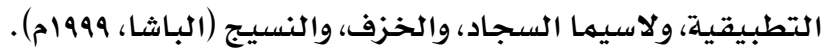
كـ السمات العامة للوحلدات الزخرفية بالعصر الأندلسي:

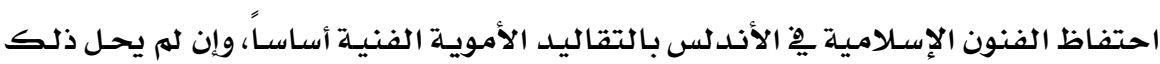
دون الإفادة مـن الأنماط الأخرى. وقد توحد الفن الأندلسي بالفن المغريـي ذي الخصائص الشرقية زمن

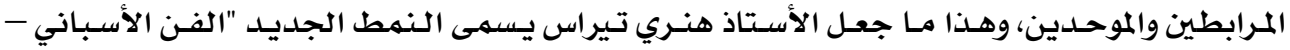

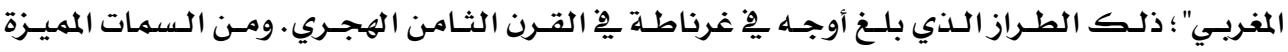
للفنون الإسلامية يِّ الأندلس: ا ـ مـرونة الفن الإسـلامي الأندلسي. r . براهية الفراغ. r. مراهية التصوير. ع. البعد عن الطبيعةة.

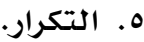

7. استخدام الألوان الطبيعيلة.

الإطار التطبيقي للدراسة:

هدفت التجربـة العملية إلى ابتكار تصميهمات زخرفية معاصـرة قائمهة على مـا تم استخلاصسه

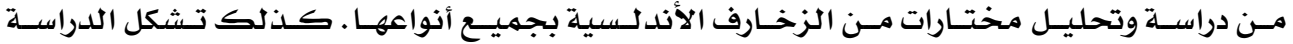
التطبيقية على تصميمـات متتنوعة بـالتطريز الآلي بصياغة العناصـر الزخرفيـة الأندلسية والاستفادة منها يخٌ إثراء مـجال الملابس وبخاصسة مـلابس النساء.

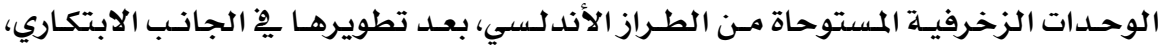

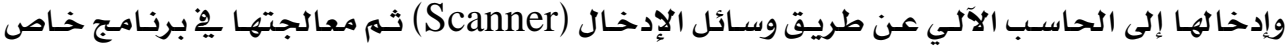
بالرسه والتصهيه (Adobe Illustrator Program) حيـث قامـت البـاحثة بإدخـال جميـع الوحسدات

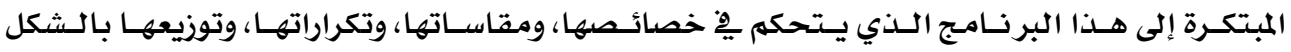

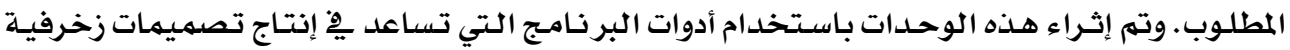

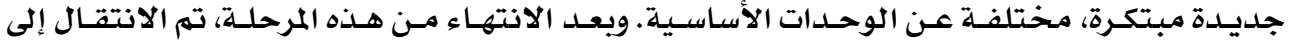
مـرحلـة هامــة وهـي مـرحلـة الحـصول على وحسدات مطـرزة ؛ حيـث تم نسـخ جميـع الوحسدات الزخرفيـة السـابقة إلى برنامـ آخر خاص بالتصميهم للتطريز الآلي (EOS) . وهذا البرنامج يسـاعد على معالجة التـصميمـات السـابقة، وتحويلـها إلى (قوالب) مطـرزة بأبعـاد ثلاثيـة باسـتخدام غـرز مـتنوعـة ؛ السـاتان والتتامسي ستان وبعض الغرز الخاصـة وغرزة الفلاحي وغرز جديلدة ابتكرتها الباحثة ووزعتها باستتخدام أنواع التكرارات المتتوعة التي يسـاهم البرنامـج يخ تتفيذها والتي تبدأ من التكرار البسيط وتنتهي بعمل

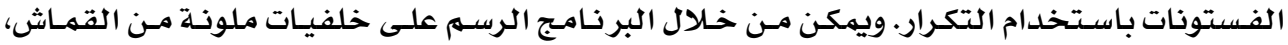


تسـاعد على ابتكار مجموعـات لونيـة متنـاسقة. وتم تجريـب هـذه الوحـدات التي تحتـوي على rا إبـرة، حيث تتميز بالسرعة والدقة العالية، ووفرة الإنتاج، وسهولة مدئة الأداء.

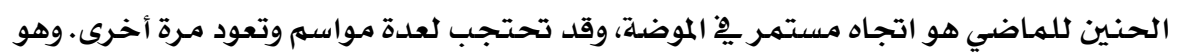

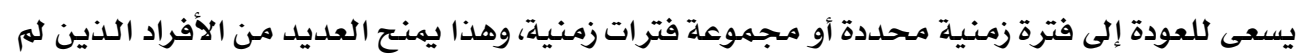

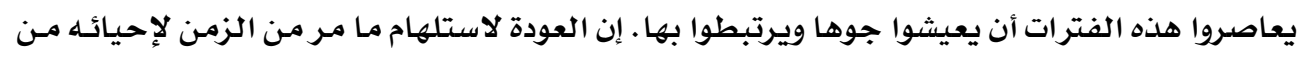

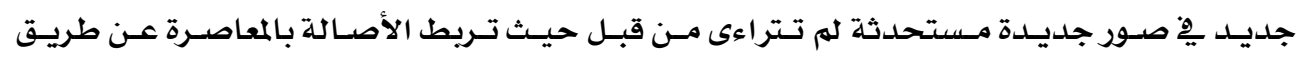

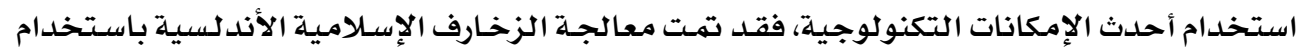

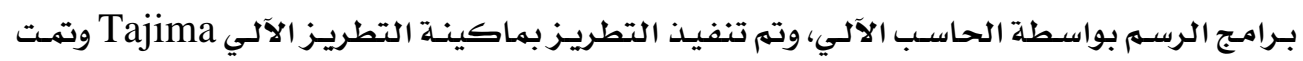

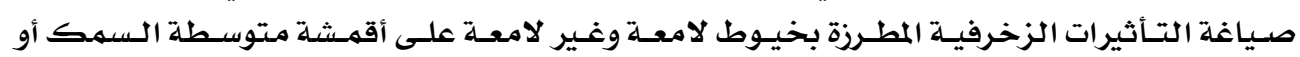

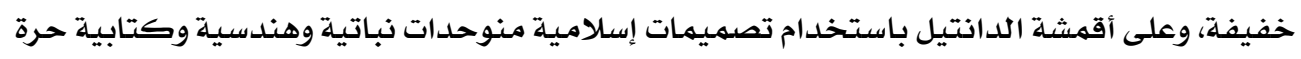

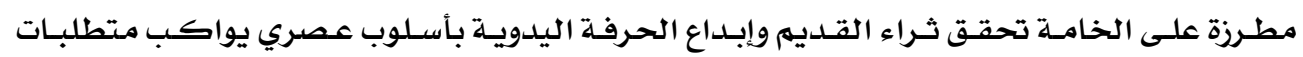
العصر من سرعة الإنجاز لتلبية رغبـات المستهلكين. التصميي الأول (ولادة المستكفي):

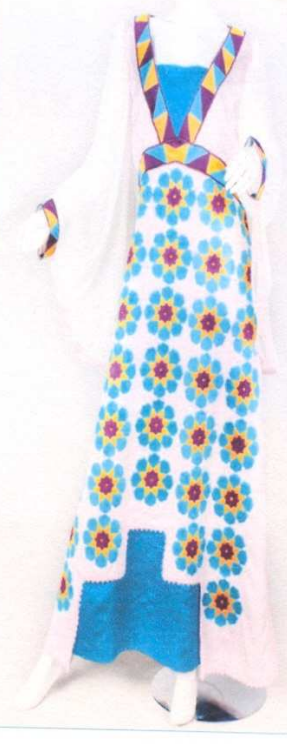

جلابيـة معاصــرة تمثـل الــروح الـشرقية بِ

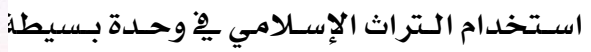
زخرفة إسلامية هندسية (طبق نجمي) وحقق الأست

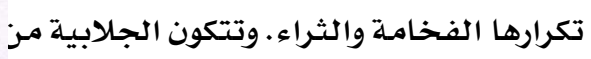

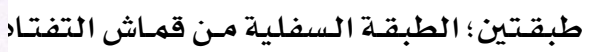

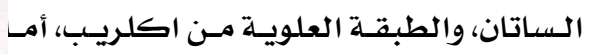

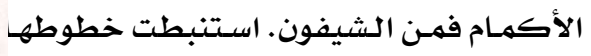

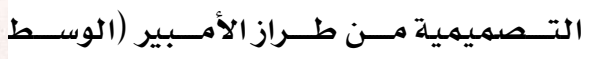

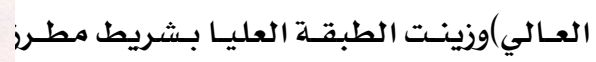

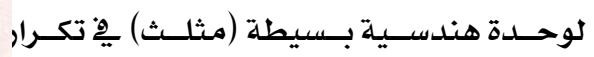
منتظم بفتحسة الصدر والأساور.

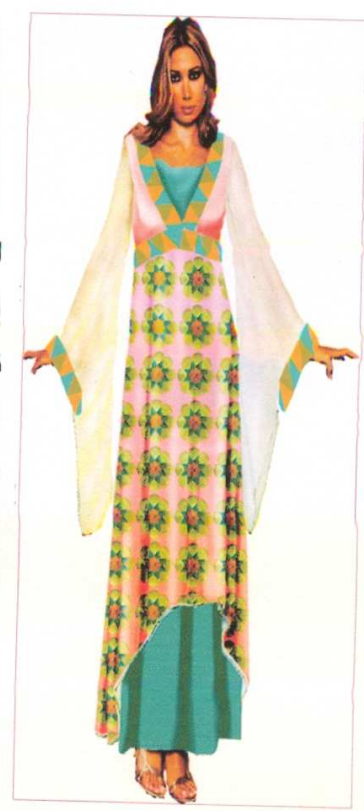




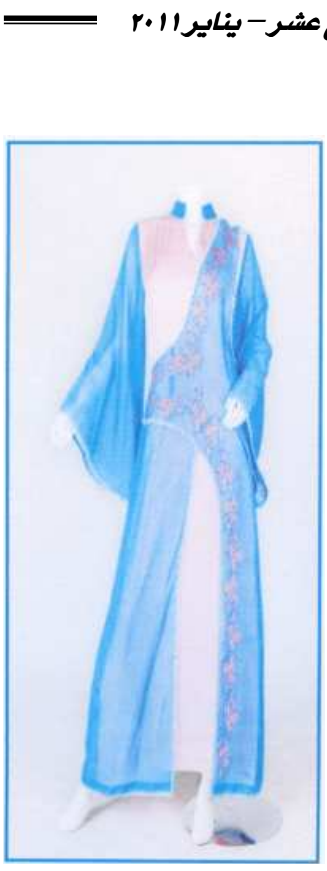

التصميه الثاني (قرطبة):

فـستان مكسسمر مــن قطعـتين منفــذ مــن قهـاش الكريسب عـدا الأكمـام كمـن قمـاش الموجـاشـل،

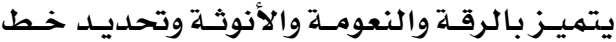

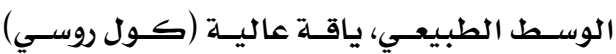
وفتحـة الصدر على شكل (V))، وتتلاءم الزخرفة

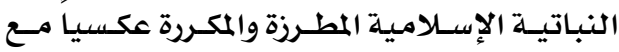
الخطـوط البنائيــة للـزي، مهــا أعطـى التــأثير المطلـوب مـن حركـة وتنغـيهم وتأكيـد خطـوط الموديل الممتدة بطول الفستان.

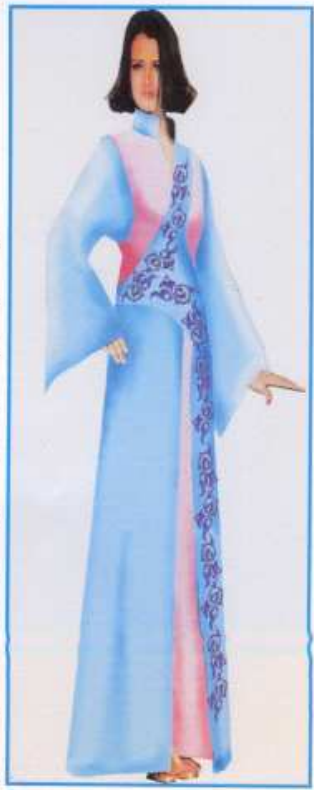

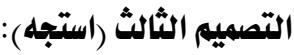
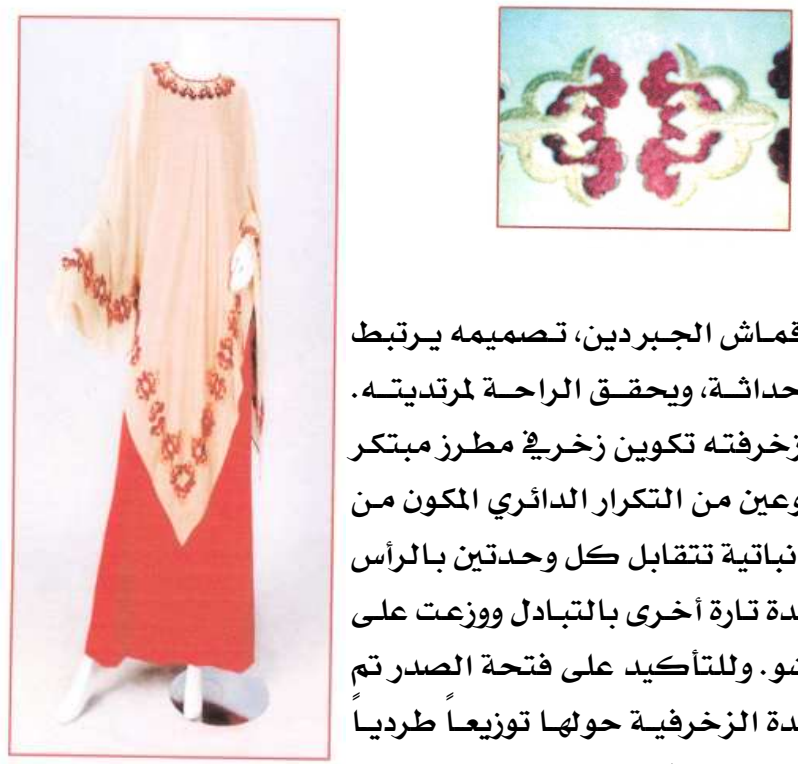

بونشو مـن قهـاث الجـبردين، تصميهمه يـرتبط

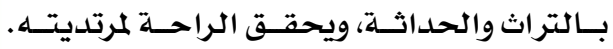
استخدم يٌْزخرفته تكوين زخريف مطرز مبتكر باستخدام نوعين مـن التكرار الدائري المكون مـن أريع وحدات نباتيـة تتقابل كل وحسدتين بـادرأس تـارة وبالقاعدة تـارة أخـرى بـالتبـادل ووزعت على وحسلى أطراف البنشو. وللتأكيد على فتحة الصدر تم توزيــع الوحسدة الزخرفيـة حولهـا توزيعـاً طرديـا مها يحقق التناسب والانسسام.

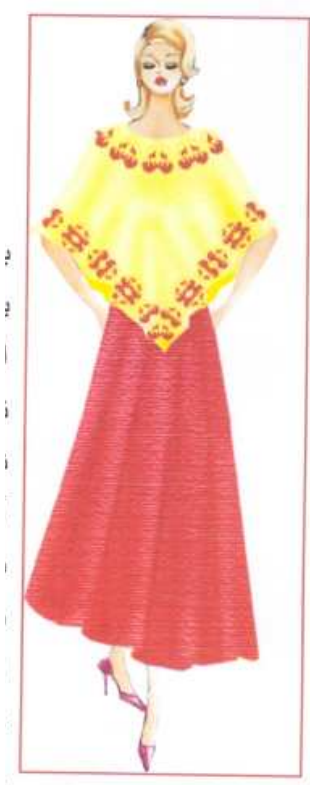



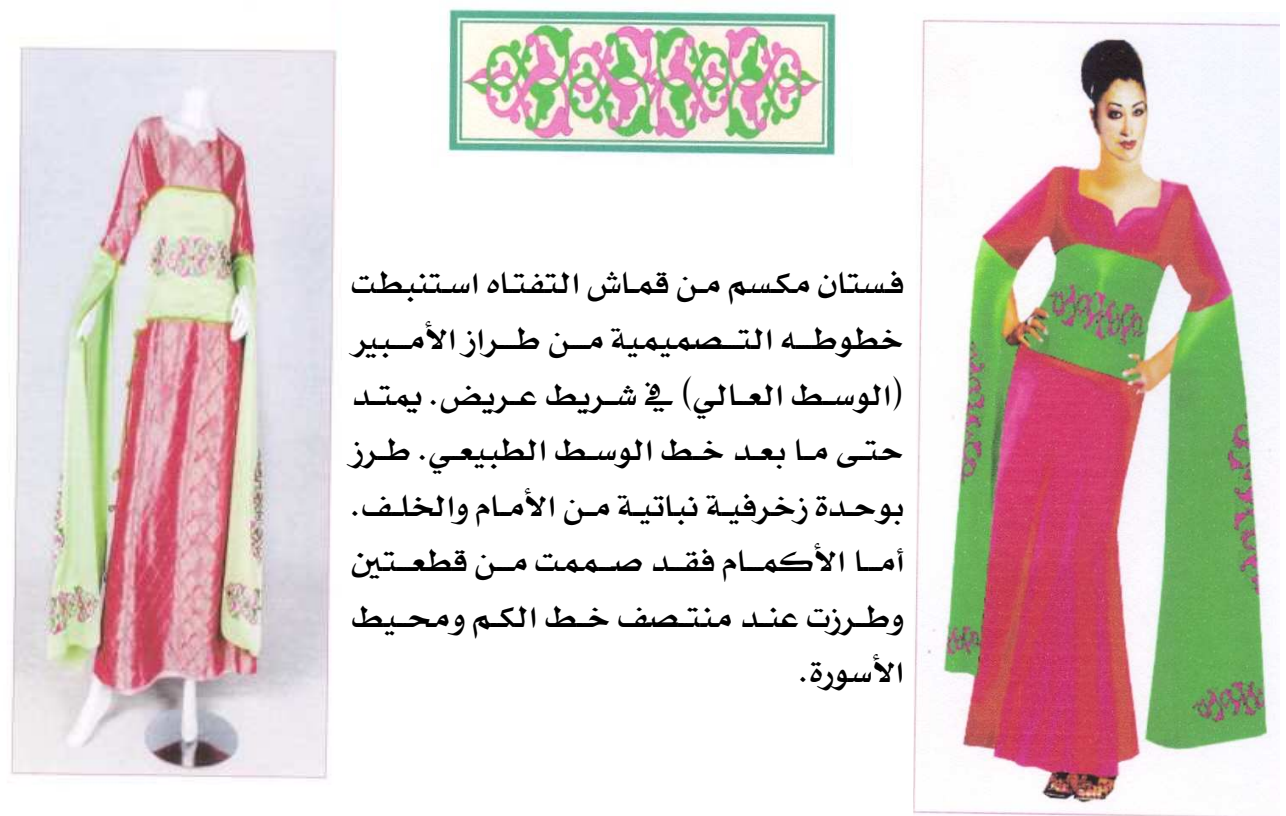

النتائج:

استخلـصت الدراسـة الكثثير مـن النتـائج الـتي انبثقـت مـن تفاعل كـل مـن الإطـار النظـري

والتطبيقي للدراسة. ويمكن إيجازها يِّ التالي:

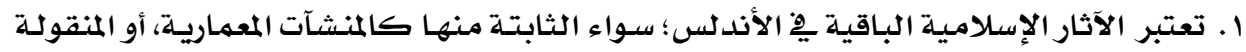

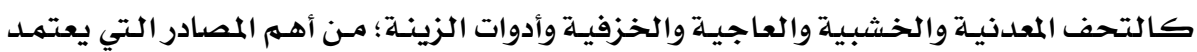

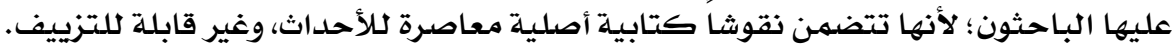

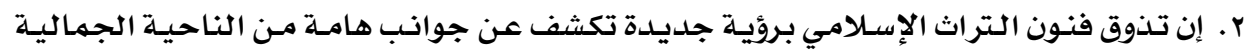

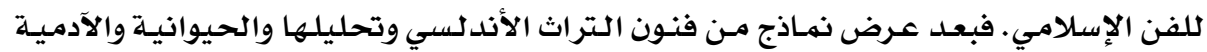

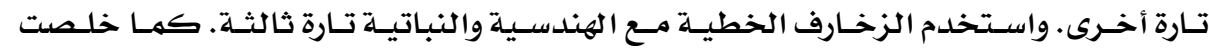

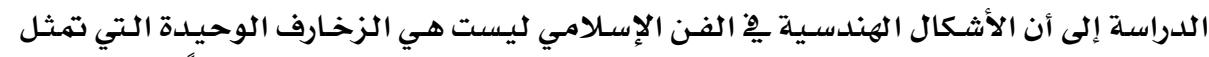

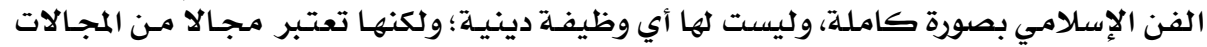

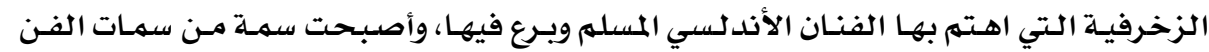

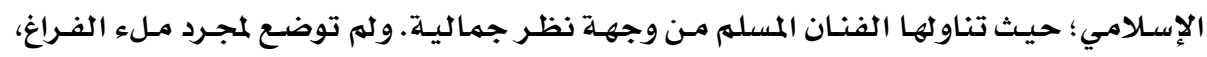

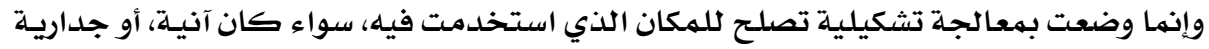
أو قطعة نسيج مطرزة. 
r. دراسـة وتحليـل وتـصنيف مختــارات مـن زخــارف الطـراز الأندلسـي (النبـاتيـة - الهندسـية -

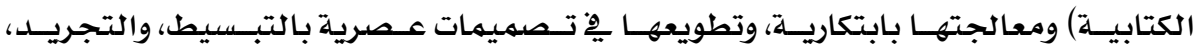

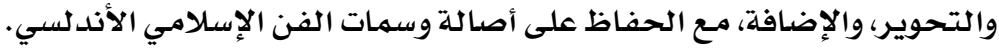

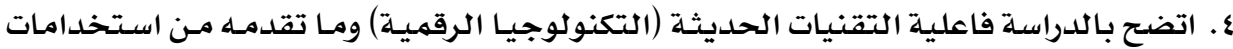

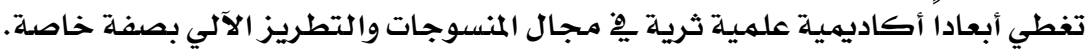

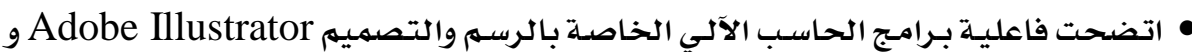
Adobe Photo Shop الإسلامي، واستخدامها يِّ تكوينات زخرفية بالتكرارات المختلفة.

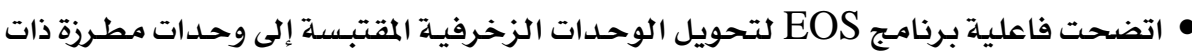

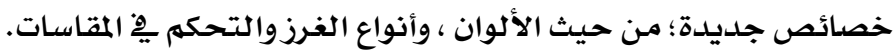

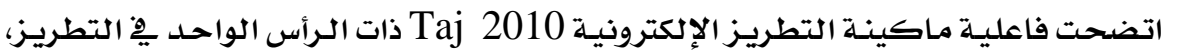

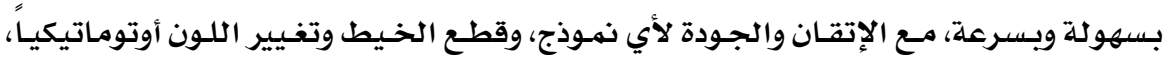

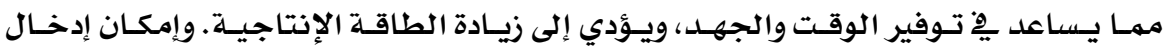

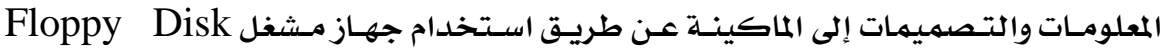

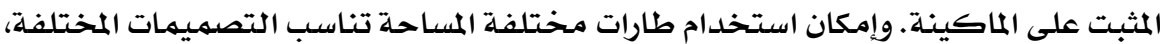

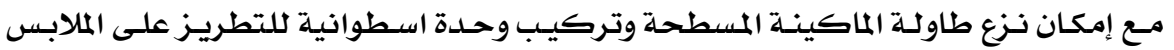
Taj الجاهزة أو الأنبوبية كالكم والبنطلون، والقبعات.

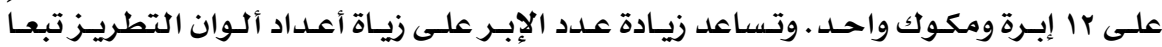

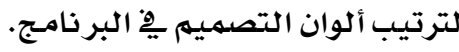
• اتضحت فاعلية ماكينة الخياطة والتطريز Singer Futura كأحد النماذج التي أنتجتها

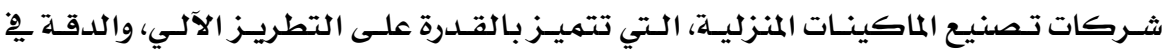

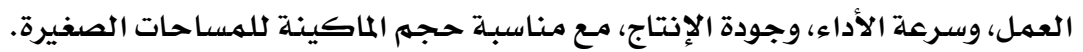

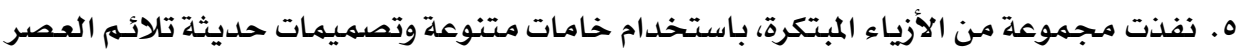

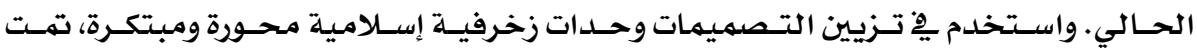

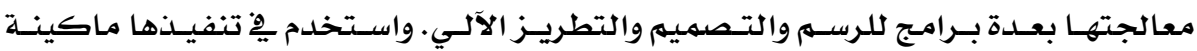
التطريز الإلكترونية.

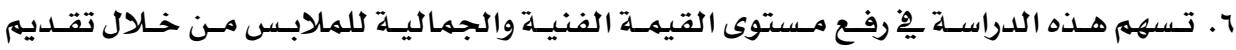

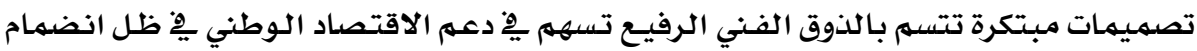

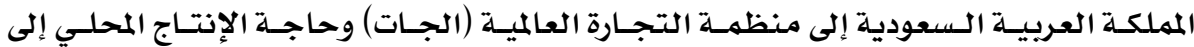
التطوير والمنافسلة. 
V. استخدام التقنيات الحديثة ِِّ صياغة التأثيرات الزخرفيـة المطرزة بخيوط لامعـة وغير لامعـة

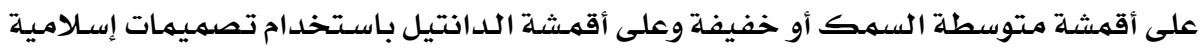

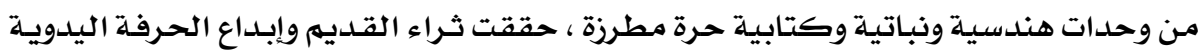

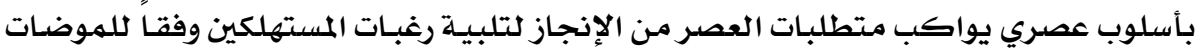

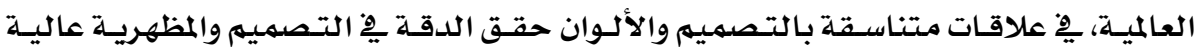

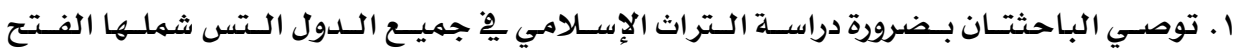

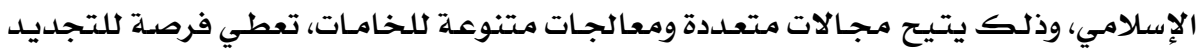

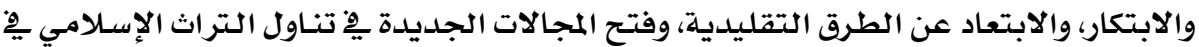

$$
\text { أغراض تعليمية وفنية معاصرة. }
$$

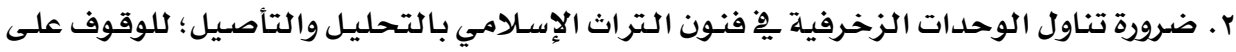

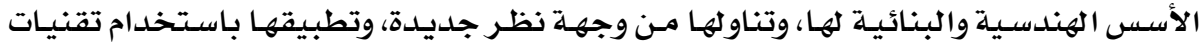

$$
\text { حديثة تناسب العصر الحالي. }
$$

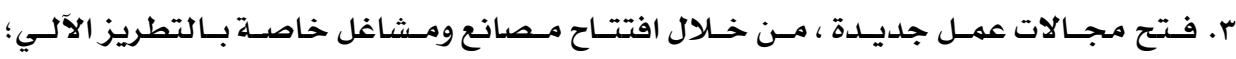

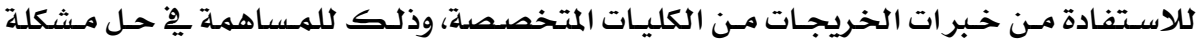

$$
\text { البطالة. }
$$

ع. الربط بين الجامعـات وبـين سـوق العمل، مـن خـلال إعداد كـوادر جامعيـة فنيـة مدريـة يتطلبهـا

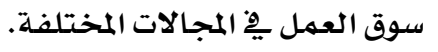

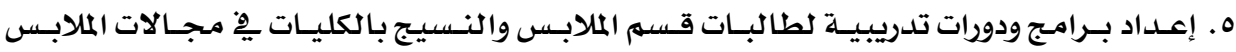

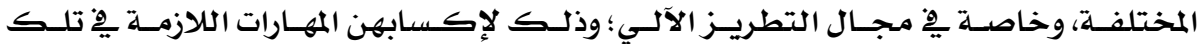

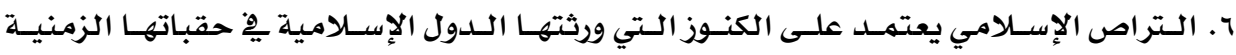

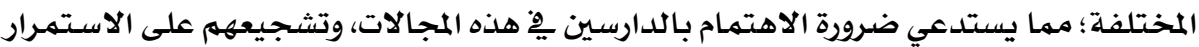

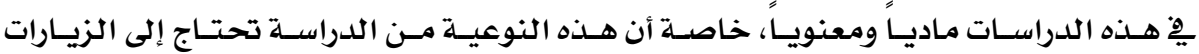

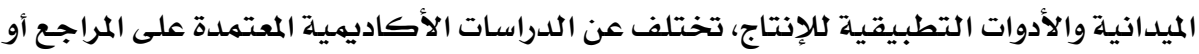

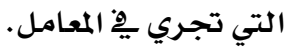


مجدي عزيز (.... م) : "موسوعة المناهج التربوية" مكتبة الأنجلو المصرية: القاهرة.

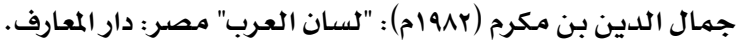

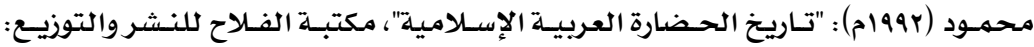

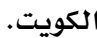

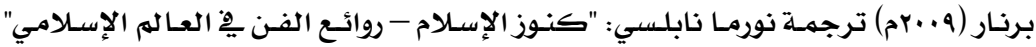

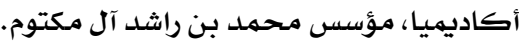

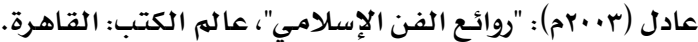

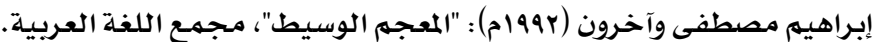

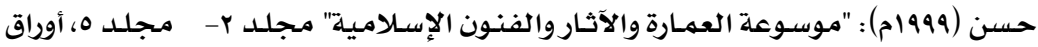

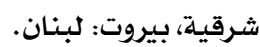
حسن (1991/م): "مدخل : لبنان إلى الآثار الإسلامية"، دار النهضة العربية: القاهرة.

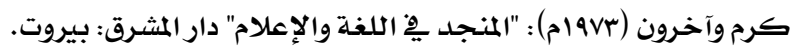
زكي محمد (د.ت.): "فنون الإسلام"، دار الفكر العربـي.

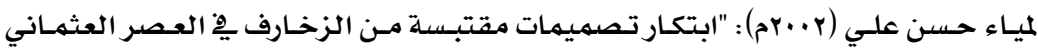
وتوظيفها لإثراء تكنولوجيا التصميم الزخريٌ والتطريز باستخدام الحاسب الآلي" رسالة

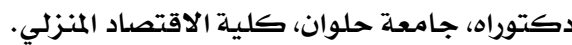

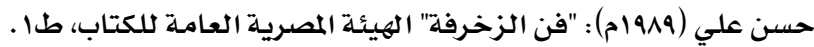

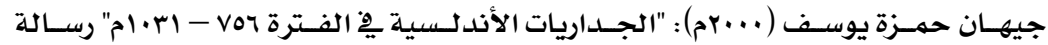

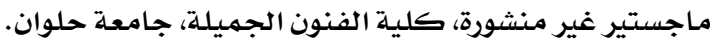

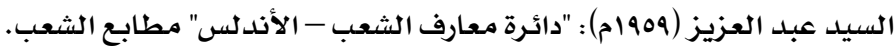

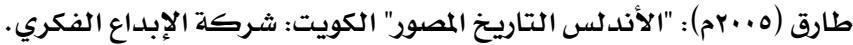

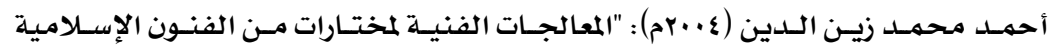

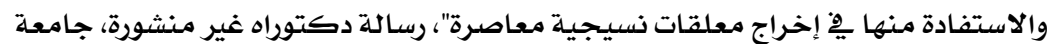
حلوان، كلية الفنون التطبيقية.

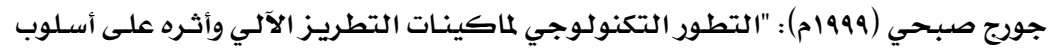
التشغيل"، رسالة ماجستير، كلية الاقتصاد المنزلي، جامعة حلوانوان المان.

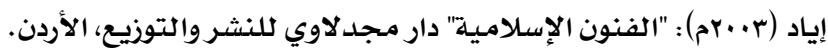

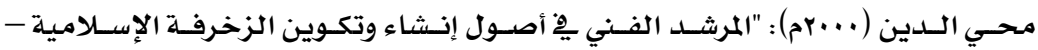

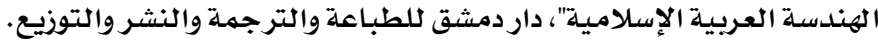

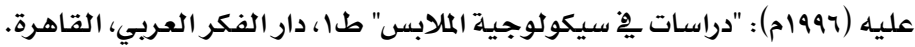

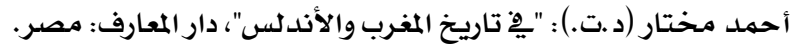

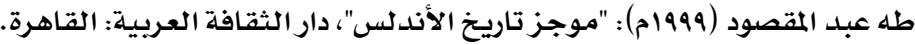

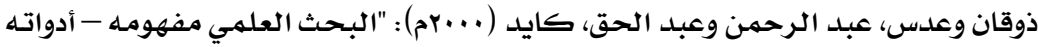

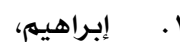

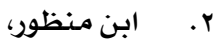
r. إسماعيل، ؟. أوكان،

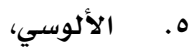
1. v. ل الباشا،

1. الباشا، 9 9. •1. 11. حسن،

rr. rا. زهران، عا. ساله، 10. السويدان، 17. الشريف،

V ا. صدقي، 11. الصقر، 19. طالو، •r. اיץ. العبادي، r. r r. عبيدات، 
- أساليبه"، الرياض : دار أسامة للنشر والتوزيع.

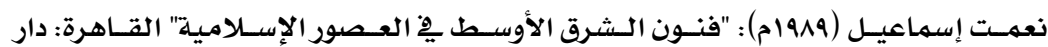

( - n

المعارف.

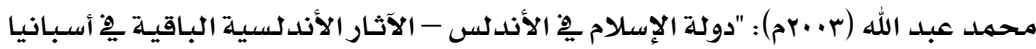

0. عنان،

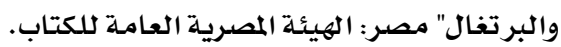

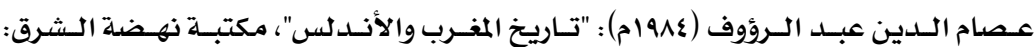

القاهرة.

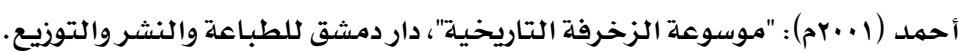

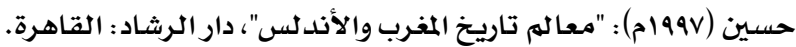

rV

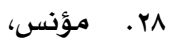

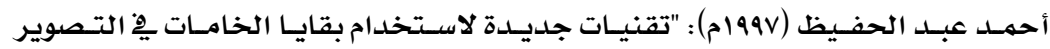

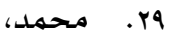

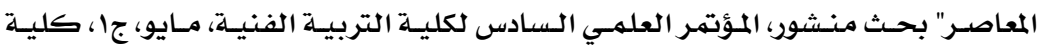

التربية الفنية، جامعة حلو ملوان.

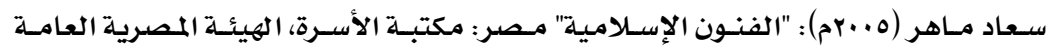

r.r. محمد،

للكتاب.

سعاد ماهر (19Vv) ) : "النسيج الإسلامي"، دار الشعب، القاهرة.

ابr. محمدل،

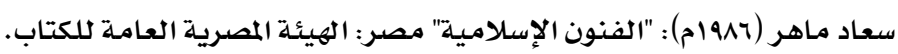

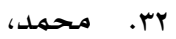

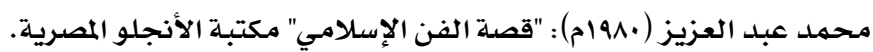

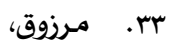

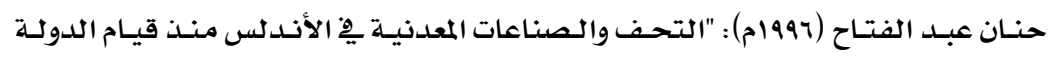

عـ. مطاوع، مروق،

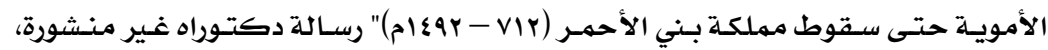

جامعة الإسكندريـة.

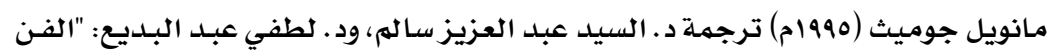

مr. مورينو،

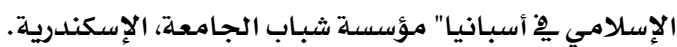

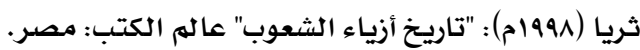

צח. نصر،

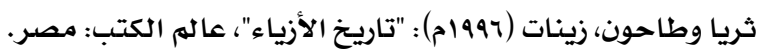

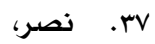

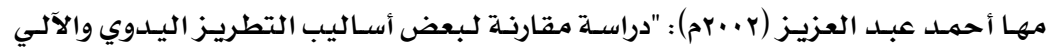

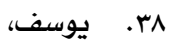

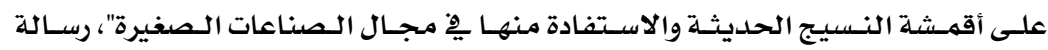

ماجستير، كلية الاقتصاد المنزبي، جامعة حلوان.

ثانياً: المراجع الأجنبية:

39 Ryan, M.G.; 2002: "The Complete Encyclopedia of Stutchery" Barnes \& Noble Books, New York.

المواقع الإكترونية:

40 http://home.earthlink.net/ lilinah/Costuming/andalus 13c.html 